\title{
The Role of Green and Blue Hydrogen in the Energy Transition-A Technological and Geopolitical Perspective
}

\author{
Michel Noussan*(D), Pier Paolo Raimondi ${ }^{(D)}$, Rossana Scita and Manfred Hafner \\ Fondazione Eni Enrico Mattei, Corso Magenta 63, 20123 Milano, Italy; pierpaolo.raimondi@feem.it (P.P.R.); \\ rossana.scita@gmail.com (R.S.); manfred.hafner@feem.it (M.H.) \\ * Correspondence: michel.noussan@feem.it
}

Citation: Noussan, M.; Raimondi, P.P.; Scita, R.; Hafner, M. The Role of Green and Blue Hydrogen in the Energy Transition: A Technological and Geopolitical Perspective. Sustainability 2021, 13, 298. https://doi.org/10.3390/su13010298

Received: 12 December 2020 Accepted: 28 December 2020 Published: 31 December 2020

Publisher's Note: MDPI stays neutral with regard to jurisdictional clai$\mathrm{ms}$ in published maps and institutional affiliations.

Copyright: (C) 2020 by the authors. Licensee MDPI, Basel, Switzerland. This article is an open access article distributed under the terms and conditions of the Creative Commons Attribution (CC BY) license (https:// creativecommons.org/licenses/by/ $4.0 /)$.

\begin{abstract}
Hydrogen is currently enjoying a renewed and widespread momentum in many national and international climate strategies. This review paper is focused on analysing the challenges and opportunities that are related to green and blue hydrogen, which are at the basis of different perspectives of a potential hydrogen society. While many governments and private companies are putting significant resources on the development of hydrogen technologies, there still remains a high number of unsolved issues, including technical challenges, economic and geopolitical implications. The hydrogen supply chain includes a large number of steps, resulting in additional energy losses, and while much focus is put on hydrogen generation costs, its transport and storage should not be neglected. A low-carbon hydrogen economy offers promising opportunities not only to fight climate change, but also to enhance energy security and develop local industries in many countries. However, to face the huge challenges of a transition towards a zero-carbon energy system, all available technologies should be allowed to contribute based on measurable indicators, which require a strong international consensus based on transparent standards and targets.
\end{abstract}

Keywords: hydrogen; decarbonization; green hydrogen; blue hydrogen; energy

\section{Introduction}

Energy systems are facing a transition towards technologies that allow to decrease greenhouse gases (GHG) emissions, to face the huge challenge of climate change. Hydrogen is increasingly being considered as a potential player in national and international strategies, to be applied to different sectors from industry to transport. Dedicated hydrogen strategies and roadmaps are being developed by major world economies, including Japan [1], Germany [2], Australia [3] and the European Union [4]. Research projects and industrial applications are addressing different components of the hydrogen pathway, which include generation, transmission, storage, distribution and final uses.

Hydrogen is already a commodity that is being used as feedstock in different industrial applications, ranging from refineries to ammonia and methanol production. The global demand of pure hydrogen has increased from less than $20 \mathrm{Mt}$ in 1975 to more than $70 \mathrm{Mt}$ in 2018 [5]. Yet, current hydrogen demand is mostly supplied by fossil fuels, including natural gas, oil and coal, since they represent today the cheapest pathway, with hydrogen costs ranging from 1 to 3 USD per $\mathrm{kg}[6]$.

However, hydrogen has also been proposed as a potential energy carrier to support a wider deployment of low-carbon energy, mainly produced from renewable energy sources (RES). Different waves of enthusiasm have supported the narrative of low-cost clean hydrogen at the basis of an alternative to fossil fuels, mainly exploiting fuel cells applications in the transport sector. Previously, three different moments have seen a scientific and industrial interest in the potential of hydrogen technologies [5]. The first time happened during the oil crises of the 1970s, as the world was looking for alternative solutions to face potential oil shortages and tackling environmental problems such as local pollution and acid rains. Research programs and activities on hydrogen were implemented, but they 
did not lead to significant effects since due to new oil discoveries the oil prices eventually decreased and the fear of shortages disappeared. Other two waves of enthusiasm happened in the 1990s and in the 2000s [7], with rising concerns related to climate change issues and peak oil scenarios. Again, low oil prices limited the diffusion of hydrogen technologies, and so did the economic and financial crisis of the end of 2000s.

Today, a growing consensus is building up again on the potential of hydrogen, mostly due to a stronger climate agenda with challenging targets. Clean hydrogen is part of a group of technologies that need to be deployed across final uses to ensure a transition towards climate-friendly energy sources [8]. Hydrogen technologies are also being considered as an opportunity to develop national industrial sectors, in a recovery perspective after the COVID-19 pandemic.

Hydrogen generation technologies are increasingly being codified by referring to a scheme based on different colors $[9,10]$. The main colors that are being considered are the following:

- $\quad$ grey (or brown/black) hydrogen, produced by fossil fuels (mostly natural gas and coal), and causing the emission of carbon dioxide in the process;

- blue hydrogen, through the combination of grey hydrogen and carbon capture and storage (CCS), to avoid most of the GHG emissions of the process;

- turquoise hydrogen, via the pyrolysis of a fossil fuel, where the by-product is solid carbon;

- $\quad$ green hydrogen, when produced by electrolyzers supplied by renewable electricity (and in some cases through other pathways based on bioenergy, such as biomethane reforming or solid biomass gasification);

- $\quad$ yellow (or purple) hydrogen, when produced by electrolyzers supplied by electricity from nuclear power plants.

In addition to these colours, different nomenclatures are often in use when referring to groups of hydrogen pathways, including "clean hydrogen", "low-carbon hydrogen", "renewable hydrogen". These definitions may sometimes be confusing, since there is no unique standard to provide a common reference. In this paper, the term low-carbon hydrogen includes green, blue, turquoise and yellow hydrogen. Yet, it is important to remember that also within each "colour", there may be a significant variability of carbon intensity, due to a large number of parameters. In some cases, hydrogen may be even carbon-negative, such as with pathways that involve bioenergy and CCS together. A scheme of the main different pathways is reported in Figure 1. Additional pathways exist, but they are still at research stage and they have not been included.

While each technological pathway presents opportunities and limitations, it is important to remember that the choice of a specific solution is often related to additional aspects, including geopolitical choices based on national strategies driven by the availability of resources, energy security concerns or the support to specific industrial sectors [11]. Moreover, cross-border hydrogen trade, due to the need of a very strong decarbonization of energy systems in the next decades, can become a potential game changer in global energy geopolitics [12].

A widespread and effective development of green hydrogen requires a notable amount of renewable electricity, which may be a problem in the short term, since RES are already needed to decarbonize existing electricity demand. For this reason, blue hydrogen can represent a useful option on the short and medium term, by helping in paving the way for green hydrogen at a later stage [13].

This review paper presents the main aspects related to the potential evolution of hydrogen-based technologies in the decades to come. This paper focuses on green and blue hydrogen pathways, which are the two approaches that are mostly being considered by world countries to support a low-carbon hydrogen economy. The work analyzes the technological challenges and opportunities, which will be among the main drivers of the hydrogen costs, ongoing developments worldwide, as well as the consequences on geopolitics. The aim is to present an impartial description of the different perspectives that 
exist worldwide, as well as to provide a picture of the complexity of the supply chain that needs to be developed.
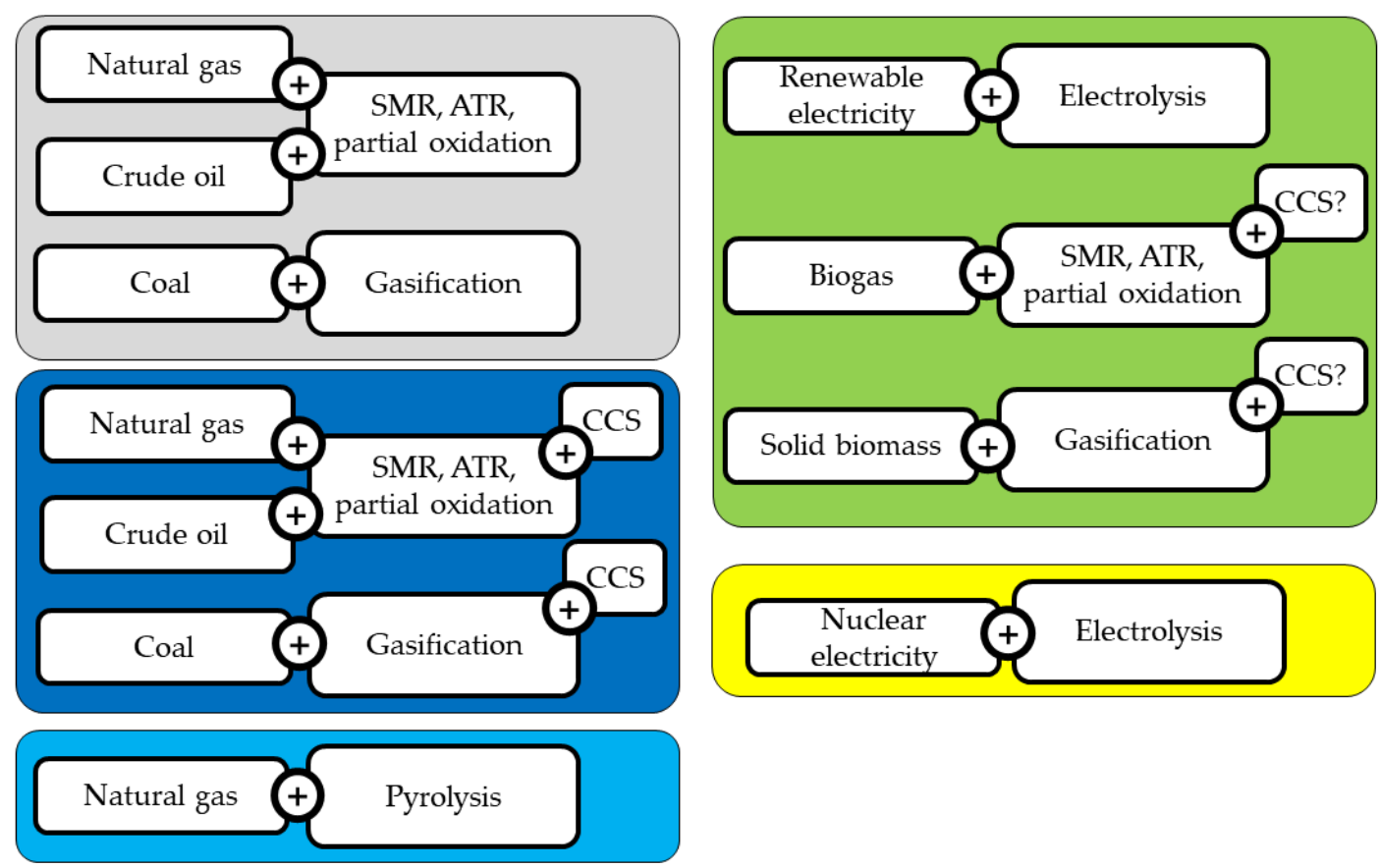

Figure 1. Different hydrogen generation pathways divided by colour. SMR: steam methane reforming, ATR: autothermal reforming, CCS: carbon capture and sequestration.

The paper is organized as follows-Section 2 provides a description of the main technological aspects related to hydrogen, including technologies for the generation, distribution and storage, as well as on the potential applications of hydrogen in different final sectors, including industry, transport, buildings and power generation. Section 3 focuses on the geopolitical dimension of hydrogen, with a discussion and comparison of different national strategies, the potential role of private companies as well as agreements between countries. Finally, Section 4 presents a critical discussion on the main topics that have been addressed, together with some policy recommendations to support a sustainable and effective use of hydrogen in the context of the energy transition.

\section{Technological Aspects}

Various technological challenges need to be addressed throughout the long and complex hydrogen supply chain, which is in general affected by a relatively low efficiency resulting in high costs for the final users. While much attention is generally put on hydrogen generation, either via green or blue pathways, also storage, transport and final uses equipment may entail additional costs and barriers. This section presents the main aspects that are at play along the entire supply chain, by discussing the current situation and the potential future evolution.

\subsection{Hydrogen Generation}

Although hydrogen is the third most abundant chemical element on Earth's surface, after oxygen and silicon, it is not available in its pure form, and thus it cannot be considered an energy source. Conversely, hydrogen is an energy carrier that should be produced from other sources. Although hydrogen generation from water through electrolysis dates back to the 19th century, today's hydrogen demand is mostly fulfilled by other processes based on fossil fuels (natural gas, coal and oil), including steam methane reforming (SMR), autothermal reforming (ATR), partial oxidation and coal gasification. Those processes 
are usually referred to as grey hydrogen pathways. When coupled to CCS, they can be transformed to low-carbon solutions, and they are called blue hydrogen pathways.

Conversely, hydrogen generation from water electrolysis, which was abandoned due to higher costs, can be coupled to power generation from RES to produce green hydrogen. While current costs remain higher than fossil-based solutions, the expected learning curves for both RES electricity generation and electrolyzers could make it a viable solution in the next decades. An estimation of future cost trends for green and blue hydrogen is reported in Figure 2, based on estimations from BNEF data [14]. The figure reports the costs both in terms of hydrogen mass, on the left axis, as well as in terms of energy content, considering hydrogen's lower heating value (120 MJ per $\mathrm{kg}$, or $33.3 \mathrm{kWh}$ per $\mathrm{kg}$ ). Renewable hydrogen costs are based on large projects with optimistic projections for capital expenditure. Blue hydrogen is based on natural gas prices of USD 1.1-10.3/MMBtu, and coal prices of USD $40-116 / t$. The uncertainty of future cost ranges is related to multiple aspects.

\section{Global cost of hydrogen production}

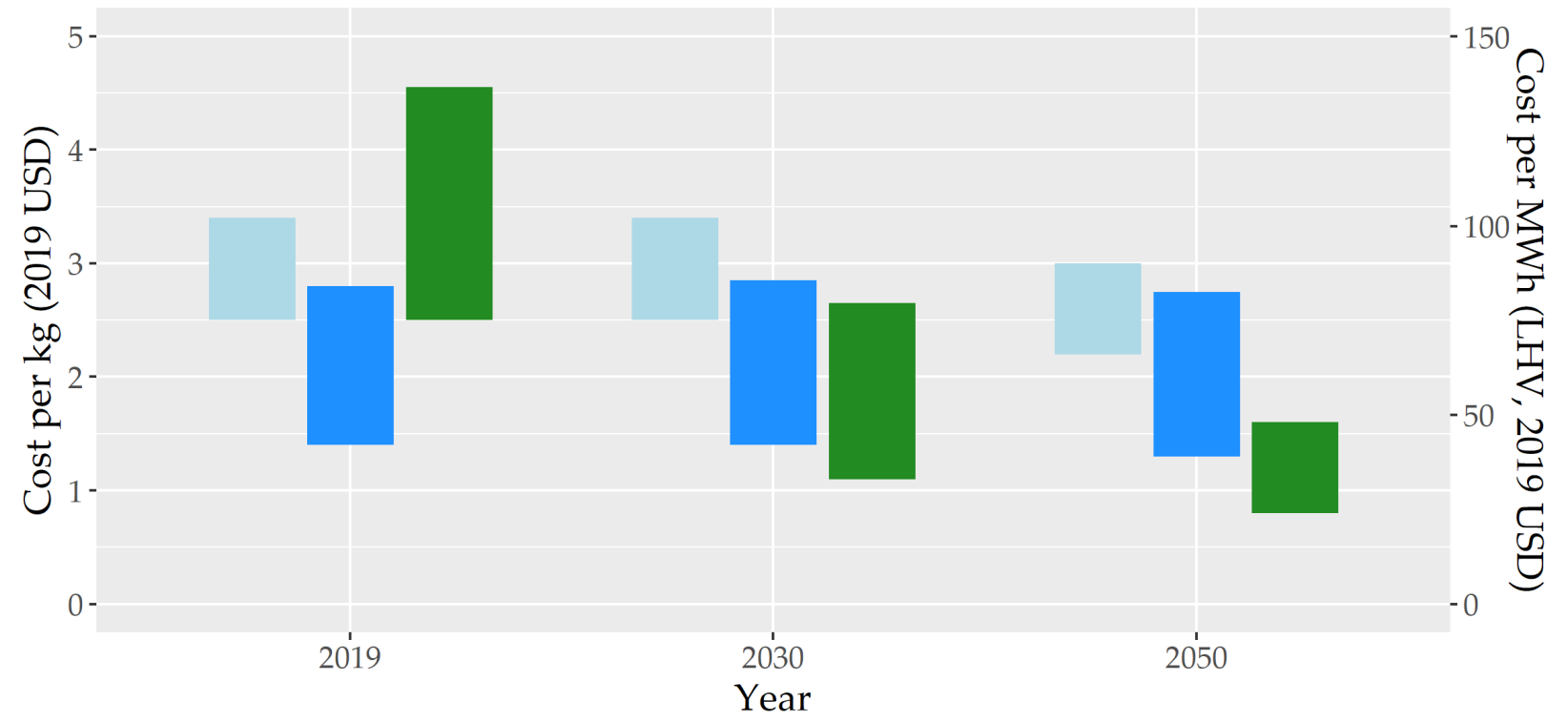

Blue hydrogen (coal)

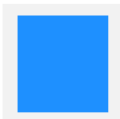

Blue hydrogen (gas)

Green hydrogen

Figure 2. Estimation of future hydrogen costs for different pathways. Energy figures based on hydrogen lower heating value (LHV). Authors' elaboration on BNEF data, 2020 [14].

Other studies report comparable values and future estimations. The International Renewable Energy Agency (IRENA) estimate a levelized cost of hydrogen by 2050 as low as 0.95 USD per kg when produced from wind electricity, and as low as 1.2 USD per $\mathrm{kg}$ when based on solar electricity [8].

Additional details on those pathways are discussed in Sections 2.1.1 and 2.1.2.

In addition to green and blue hydrogen pathways, it is important to remark that other options may be considered, in particular in specific countries or regions. Hydrogen production from nuclear electricity $[15,16]$ is rarely mentioned in European strategies, but it may become a viable alternative in different world regions, such as China [17] and Russia [18]. Other solutions for renewable hydrogen may be based on biomass gasification or SMR based on biogas feedstock, although these solutions may be harder to scale-up than electrolysis. 


\subsubsection{Green Hydrogen}

The green hydrogen pathway is defined as the combination of power generation from renewable sources and water electrolysis. By supplying electricity and pure water to an electrolyzer, output flows of hydrogen and oxygen are produced.

Different technologies are available for water electrolysis. Alkaline electrolyzers represent the state of the art, and proton exchange membrane (PEM) technologies are in a demonstration phase, while solid oxide electrolyzers are still in an R\&D pipeline [19]. PEM electrolyzers may provide a range of advantages for a comparable energy consumption, including higher output pressures, a better partial load range, and quicker startup and load variations [20]. Considering global electrolyzers deployment, annual capacity additions have reached $25 \mathrm{MW}$ in 2019, but announced projects are scaling up quickly, and they will reach 1.5 GW of new capacity in 2023, with the largest project accounting for 540 MW alone [21].

Current industrial solutions show a range of electricity consumption depending on the size and the type of electrolyzer, as well as on the output pressure that is considered. Average electrolysis efficiency, defined as the ratio of hydrogen energy content (measured as higher heating value) and electrolysis power consumption, is in the range $65 \%-70 \%$ (when considering output pressures of 10-30 barg) [22].

An additional issue related to electrolysis is water consumption. Pure water consumption is generally in the range of 10-15 L per kg of hydrogen output [23], and input water needs to be deionized. In the absence of freshwater sources, option include seawater desalination or wastewater recovery. Different technologies are already commercially deployed for seawater desalination, and they could be coupled with electrolysis with a very limited increase of energy consumption [24]. However, water availability in non-maritime sites may become a serious issue in many world regions, especially due to the fact that water scarcity is a serious concern that will become even worse due to climate change. This aspect may become a critical barrier in the success of green hydrogen projects in areas that have a strong solar potential, such as deserts.

The generation cost of green hydrogen is generally considered in the range 2.5-4.5 USD per kg [14], although other sources estimate higher values. The two most significant components of the cost are the investment cost of the electrolyzer and the electricty cost, which represents around $90 \%$ of the OPEX costs. Current CAPEX costs for alkaline electrolyzers are around $750 \mathrm{EUR} / \mathrm{kW}$ (around $900 \mathrm{USD} / \mathrm{kW}$ ), and they are expected to decrease to around $500 \mathrm{EUR} / \mathrm{kW}$ (around $600 \mathrm{USD} / \mathrm{kW}$ ) by 2025 [20]. Experts estimate that around $80 \%$ of the cost is attributable to OPEX (when considering 4000 operational hours per year), thus the cost of electricity is a crucial driver of the green hydrogen cost.

However, a trade-off exists between the electricity price and annual operational hours. Business models based on exploiting electricity curtailments in power networks can benefit from zero or even negative electricity prices, but for a very limited number of hours, with an unsustainable weight of CAPEX. Moreover, Cloete et al. [25] results suggest that, depending on the location of electrolyzers, greater capital expenditures may be also required for hydrogen pipelines and storage infrastructure (to handle intermittent hydrogen production) as well as electricity transmission networks (to transmit electricity surplus to electrolyzers). Additional potential constraints related to the current configuration of power systems are reported by other scholars [26].

Conversely, operating an electrolyzer on grid electricity means paying additional taxes and levies, in addition to the need of buying green certificates to ensure that renewable electricity is used. The best solution seems to integrate hydrogen production to dedicated solar or wind power plants, which can reach acceptable annual load factors in selected locations. In this case, favorable learning curves for both power generation from RES and electrolyzers, also driven by a manufacturing upscale, may bring significant cost reductions. BNEF estimates green hydrogen prices as low as 1-2.6 USD by 2030 and $0.8-$ 1.6 USD by 2050 [14]. However, other studies show that in some contexts green hydrogen generation can be already competitive today compared to the traditional production via 
fossil fuels [27]. Some scholars are also proposing to combine solar and wind energy to obtain lower generation prices [28].

It is important to remember that those costs are only taking into account hydrogen generation. There are additional costs related to the transmission, storage and distribution. As discussed below, in some cases those costs can reach even half of the final cost for the users.

\subsubsection{Blue Hydrogen}

Blue hydrogen is based on the idea that the current processes used to produce hydrogen from fossil fuels could be coupled to CCS technologies to decrease most of their GHG emissions. While this approach seems to be less costly than shifting towards green hydrogen, it is important to remember that CCS implementation may involve technical barriers, in additions to problems related to social acceptability. Blue hydrogen pathways have currently technology readiness levels (TRL) between 7 (coal gasification + CCS) and 8 (SMR + CCS) [29].

There appears to be no standard definition of the $\mathrm{CO}_{2}$ capture rate that is required to shift the definition from grey to blue hydrogen. Most studies cite maximum capture rates in the range $70 \%$ to $95 \%$, depending on the technology and the stages in which $\mathrm{CO}_{2}$ capture is applied [9]. When considering blue hydrogen based on natural gas, it is important to remember the additional impact that is caused by methane leakage in the upstream phases. Although difficult to be precisely quantified, this aspect is often overlooked in research studies.

A reference threshold to define low-carbon hydrogen (i.e., blue hydrogen) has been proposed by the CertifHy Steering Group in 2019 (a project developed to reach a common European-wide definition of green and low-carbon hydrogen), by considering a $60 \%$ reduction of GHG emissions in comparison with a benchmark process based on SMR [30]. This threshold has been set to $36.4 \mathrm{gCO}_{2} \mathrm{e} / \mathrm{MJ}\left(131 \mathrm{gCO}_{2} \mathrm{e} / \mathrm{kWh}\right)$, starting from a benchmark value of value of $91 \mathrm{gCO}_{2} \mathrm{e} / \mathrm{MJ}$ of hydrogen $\left(328 \mathrm{gCO}_{2} \mathrm{e} / \mathrm{kWh}\right)$.

Blue hydrogen pathways have the advantage of building on existing industrial experience from grey hydrogen, and in some cases retrofitting of existing plants could be performed by adding CCS systems. However, specific conditions need to be met to ensure an effective and durable storage of $\mathrm{CO}_{2}$. Often an additional infrastructure may be needed to connect the generation facility with the storage site, which may not be available on place. A dedicated $\mathrm{CO}_{2}$ infrastructure may increase significantly the total cost, an aspect that is difficult to generalize since it depends on each plant. In addition, the operation of a CCS system may decrease the energy efficiency of a SMR process by $5 \%-14 \%$ [29].

Also for blue hydrogen pathways, water consumption is an aspect that is often overlooked. While water consumption is often associated to the electrolysis process, also blue hydrogen pathways consume a significant amount of water, and in some cases even higher. When comparing embodied water following a life cycle inventory, results show that water consumption per $\mathrm{kg}$ of $\mathrm{H}_{2}$ can be as high as $24 \mathrm{~L}$ for SMR and $38 \mathrm{~L}$ for coal gasification [23].

Finally, an additional pathway that is sometimes referred as turquoise hydrogen, and which is still at a TRL of 3-5 [23], is the pyrolisis of methane. Different technological solutions are currently under development, in several locations worldwide, including in Australia, Germany and France [31]. In the process, natural gas is used as feedstock, while the energy consumption would come from electricity, presumably from low-carbon sources. Methane is split at high temperatures into hydrogen and solid carbon (also called carbon black), which would be easier to store and manage than gaseous $\mathrm{CO}_{2}$. In addition, solid carbon can have industrial uses, and thus be seen as a resource instead of a by-product. The current industrial market for carbon black, including applications in tyres production and inks for printers, could support up to $5 \mathrm{Mt}$ per year of blue hydrogen, around $7 \%$ of the current global market of pure hydrogen [31]. 


\subsection{Hydrogen Transportation and Storage}

The transportation of hydrogen is a crucial aspect in the sustainability of the supply chain, both in environmental and economic perspectives. Hydrogen transport could require significant energy consumption, either to compress or liquefy it, or to convert it to another chemicals that are easier to handle, such as ammonia or other liquid organic hydrogen carriers (LOHC). Another option, although mostly in early stages of development, is the possibility of blending hydrogen in the existing natural gas grids.

An additional aspect of the hydrogen supply chain is its storage, which is required at different levels, and needs to be properly addressed to respect safety procedures and minimize energy consumption and losses.

\subsubsection{Hydrogen Blending in Natural Gas Grids}

A potential option to gradually upscale hydrogen pathways is the integration in existing natural gas networks. This is being proposed in different European countries [32-34] to exploit existing assets and start to decrease the carbon intensity of natural gas by using clean hydrogen. However, such strategy has the strong limitation of not fully exploiting the higher value associated with pure hydrogen, by mixing it with natural gas to be used in combustion processes. Thus, its economic sustainability may be hard to prove, even when accounting for environmental benefits.

When considering hydrogen blending in natural gas networks, it is important to highlight the fact that the usual blending ratios are expressed as volumetric shares. However, hydrogen has a volumetric energy density that is roughly one third of the one of methane. Thus, when considering a gas blend by accounting for the energy share, that is, considering the share of hydrogen's heating value, the hydrogen share is much lower, and so are the potential $\mathrm{CO}_{2}$ emission savings associated to it. As a reference, the commonly considered volumetric hydrogen blending ratios of $10 \%$ and $20 \%$ correspond to energy ratios of $3.5 \%$ and $7.6 \%$ respectively. A representation of the variation of $\mathrm{CO}_{2}$ emissions with different blending rates is represented in Figure 3, comparing green hydrogen and blue hydrogen with a $90 \%$ capture rate.

The emissions reductions are calculated by comparing the emission factor of the methane-hydrogen blend with the emissions of natural gas. The chart is based on natural gas emissions of $200 \mathrm{~g} / \mathrm{kWh}$ and blue hydrogen emissions of $32.8 \mathrm{~g} / \mathrm{kWh}$, based on the hypothesis of $90 \%$ of CCS. Thus, a full substitution of natural gas with hydrogen could lead to $100 \%$ emissions savings when green hydrogen is used, and $84 \%$ when blue hydrogen is used (which is lower than $90 \%$ due to the conversion efficiency of natural gas in blue hydrogen). Upstream methane emissions of natural gas and blue hydrogen are not considered in this chart.

While this aspect may seem a technical detail, it is important to remember that the blending ratios that are usually discussed are not representing corresponding emission savings, and so that their potential role may often be overestimated.

A conversion of the current natural gas supply chain to accept high shares of hydrogen would require the upgrade of a large number of components, including transmission and distribution networks, gas meters, compressors, as well as final users.

Research studies highlight that the conversion of existing grids to hydrogen networks could lead to significant economic benefits when compared to the installation of new pipelines [35]. However, in addition to the need to adapt materials to cope with problems related to corrosion and hydrogen embrittlement [36], it is important to remark that given the lower energy density of hydrogen in comparison with methane, the current pipeline sizes will not be able to manage the same energy demand that is currently supplied by natural gas. Thus, current energy demand would need to be either decreased through energy efficiency measures, or in part supplied by other options, such as electrification. 


\section{$\mathrm{CO}_{2}$ emissions reduction vs. $\mathrm{H}_{2}$ volumetric blending}

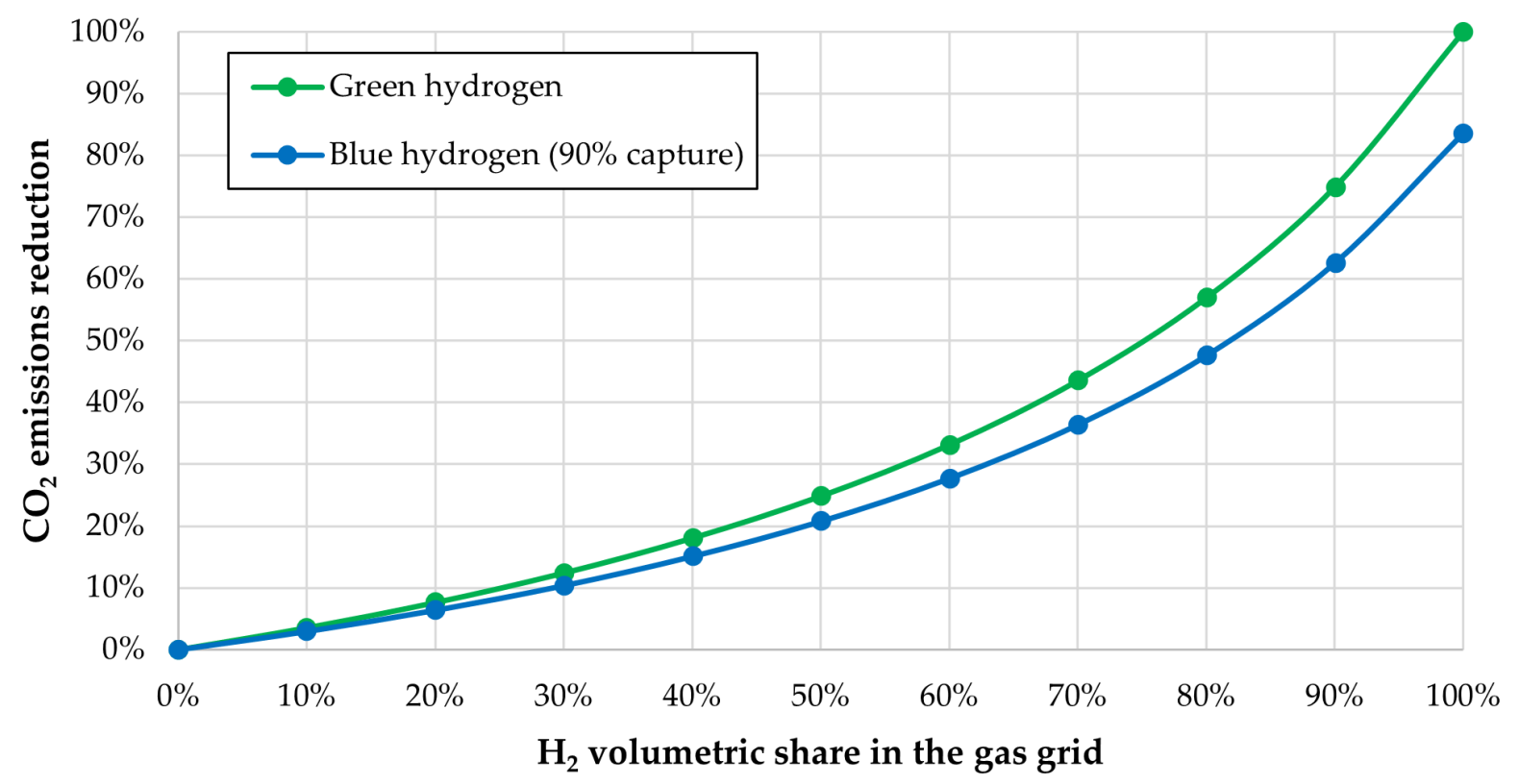

Figure 3. Potential $\mathrm{CO}_{2}$ savings for different $\mathrm{H}_{2}$ volumetric blending ratios in the natural gas grid (considering pure methane).

\subsubsection{Long-Distance Transport}

Hydrogen is increasingly seen as a potential energy carrier to be traded globally, similarly to the current logistics of liquefied natural gas (LNG). As further discussed in the following sections, many international strategies and roadmaps are based on the idea of generating hydrogen in favorable regions (e.g., with abundance of low-cost renewable sources) and ship it to countries with high demand and few local options for its generation.

The cheapest option to transport hydrogen over medium distances is often via pipeline, and there are already hydrogen networks that serve industrial facilities in different countries. However, since pipeline transportation costs increase linearly with the distance, over very long distances ship transport becomes less expensive (in addition to other advantages related to flexibility, etc.). As for natural gas, the economic sustainability of pipelines is improved by high volumes and a continuous supply over several years. This results in the need of long-term planning and a reduced flexibility. In contrast, shipping offers a larger flexibility, thanks to the possibility for a single exporter to supply several countries, provided that they have the proper infrastructure. This aspect has fostered the rise of LNG in the last years, and a similar logic could apply to hydrogen in the future.

Different studies compare available alternatives for seaborne hydrogen transport [37], considering environmental and economic aspects. Some studies present detailed assessments focusing on specific routes, including Norway to Europe or Japan [38], Australia to Japan and Korea [39], Chile-Japan [40], and Argentina-Japan [41]. Hydrogen transport in ships require the highest possible energy density per unit of volume, to avoid excessive costs. Since hydrogen cannot be transported in ships in its gaseous forms, other solutions are being considered.

The options that are under evaluation for long-distance hydrogen transport include liquid hydrogen, ammonia or LOHC. LOHC are organic compounds that can absorb and release hydrogen by means of chemical reactions. Liquid hydrogen implies high energy consumption for liquefaction and to maintain it at cryogenic temperatures. On the contrary, the transformation to other chemicals, such as ammonia, or the storage in LOHCs, requires additional processes that are associated with further energy consumption. These 
compounds, that can be stored more easily than liquid hydrogen, may have an advantage on very long distances.

The comparison of alternative seaborne transportation means in the available literature shows a strong dependence on supply volumes and distances. While future trends may be encouraging, it is important to highlight that there are no current commercial options for long-distance international transportation of liquid hydrogen. Some demonstration projects are being developed, such as between Australia and Japan, and they will be tested in the next years. On the contrary, ammonia is already a commodity that is currently produced and shipped on a global scale, although from fossil fuels [42]. Thus, the choice of ammonia over liquid hydrogen could take advantage of on existing and proven technologies and standards along the supply chain. Yet, ammonia production still involves additional energy consumption, and when final users require pure hydrogen, an additional conversion step is needed. Specific technologies, such as permeable membrane fuel cells are susceptible to ammonia poisoning, and they need very high levels of hydrogen purity [43].

The economics of intercontinental hydrogen ship transport will need to face lower volumetric energy densities in comparison with the current shipping of fossil fuels. Oil tankers, which are in some cases the largest ships in operation, can transport around 10.3 MWh of crude per each cubic meter of volume. LNG transport requires more space for the same energy content, since LNG has an energy density of 6.2 MWh per cubic meter. This figure is even worse for liquid hydrogen and ammonia, which have energy densities of 2.4 and 3.2 MWh per cubic meter respectively. Moreover, liquid hydrogen will need to be kept ad very low temperatures (i.e., around 20K). This will require very high-quality insulation, and the energy losses during a long trip may be significant (as further discussed in Section 2.2.4). Mitigation options are available, including the use of evaporated hydrogen to supply on-board power systems, and there is ongoing research on the possibility of applying them on large ships, although the correct removal of the evaporated hydrogen should be ensured to avoid any safety issue.

\subsubsection{Hydrogen Distribution}

In addition to long-distance transportation, hydrogen will also need to be supplied to final users. Available options include gaseous $\mathrm{H}_{2}$ transport via pipeline, or liquid or compressed hydrogen via trucks.

Literature studies focused on specific countries, such as Germany [44] or France [45], highlight that the choice of the best solution for hydrogen supply to final users depends on multiple factors. When considering hydrogen use for transport [44], a critical parameter is the density of refuelling stations: in the case of a high density of plants the economic advantage of deploying distribution pipelines becomes clear. Conversely, in areas with lower or less regular demand, gaseous compressed trailers are the best option.

When considering gas trucks, the pressure level is an additional parameter that may affect significantly the final cost of hydrogen [46]. When considering various pressure levels ranging from 250 to 540 bar, the optimal solution depends on both distance and volumes, since costs for transport, storage and compression represent various shares of the final cost. Long-distance and high volumes of hydrogen supply rely on high-pressure trucks, while for distances lower than $200 \mathrm{~km}$ trucks storing hydrogen at lower pressures show a better economic performance.

The choice of the best solution for each area will also be related to the location of hydrogen generation facilities. When considering green hydrogen, the optimal strategy of electrolyzers' location and size will depend on the availability of renewable electricity, but also on a trade-off between electricity transmission via power grids and hydrogen transportation via pipelines or trucks. A system perspective encompassing both energy carriers will be required to choose optimal solutions. 


\subsubsection{Storage}

Hydrogen storage needs to be ensured at different levels of the supply chain, and technologies and solutions depend on the physical form of hydrogen (liquid/gaseous), its volume, the duration of the storage and other operational parameters that need to be guaranteed. A major distinction arises between the storage of hydrogen required to operate its supply chain, and the large seasonal storage of hydrogen to cope with the variability of RES power plants.

The storage of hydrogen along the supply chain includes its storage at terminals, such as ports, at refuelling stations and also on the different vehicles that are used along the pathway, including ships, trucks, and also on the vehicles that use it for propulsion.

The storage of gaseous hydrogen at high pressure is generally performed in vessels of different materials, including steel, glass fiber, carbon fiber and polymers. There are currently 4 types of vessels, depending on the type of material that is used, resulting in variable weight, pressures and costs. Operating pressures vary in the range $50-100 \mathrm{MPa}$, and for a given pressure stationary solutions are generally designed by minimizing the price, while for on-vehicle storage systems both weight and cost are considered as design parameters [47].

Another option is to store hydrogen in its liquid state, but this solution is generally limited to situations in which hydrogen is already available in liquid form, since ad-hoc liquefaction entails significant energy consumption. The liquefaction of hydrogen in large industrial facilities is generally consuming $12.5-15 \mathrm{kWh}$ of electricity per $\mathrm{kg}$ of $\mathrm{H}_{2}$ [48], which is a significant share compared to hydrogen's lower heating value of $33.3 \mathrm{kWh}$ per $\mathrm{kg}$. Technological improvements could reduce electricity consumption to $7.5-9 \mathrm{kWh}$ per $\mathrm{kg}$ of $\mathrm{H}_{2}$, which is still around one quarter of the hydrogen's energy content.

Liquid $\mathrm{H}_{2}$ storage is usually affected by boil-offs of $0.2 \%-0.3 \%$ per day. The evaporation of hydrogen, which is caused by different phenomena, leads to the increase of the pressure in the tank, and thus needs to be expelled to avoid safety issues. Liquid hydrogen storage in transport systems, such as trucks and ships, shows higher levels of boil-off, but the hydrogen can be recovered to power the vehicle. Different solutions have been proposed to limit boil-off, including vacuum insulation, additional refrigeration systems or liquid nitrogen cooling [49].

The storage of hydrogen through other chemicals, such as ammonia and LOHC, presents lower challenges in terms of operational parameters (i.e., temperature and pressure), and this is the main reason that justifies the additional supply chain steps and energy consumption required by conversion processes. Ammonia can be stored in liquid state at $25{ }^{\circ} \mathrm{C}$ and moderate pressure (10 bar), by using standard steel tanks. LOHC include various compounds and chemical solutions [50], but their common feature is that they can be stored and handled in liquid state at ambient temperatures.

Small and medium scale storage is required to operate the hydrogen supply chain. Conversely, large scale seasonal hydrogen storage has been proposed as a solution to optimize the power generation from RES, especially for those that show significant variability of output over the year in some regions, such as solar [51]. Seasonal hydrogen storage requires high storage capacities and its operation involves a low number of cycles over the year. Thus, its economic profitability is related to low energy losses over long storage duration and a low cost of storage capacity [52].

Different underground options exist for hydrogen storage, including salt caverns, aquifers, or depleted oil and gas reservoirs. Currently, pure hydrogen is being stored in four locations worldwide, in the USA and the UK, all based on salt caverns [53]. Literature studies have assessed the storage potential for different regions, including Europe [54,55], China [56] and Canada [57].

An additional option for hydrogen storage, which is encountering a high interest in several research initiatives [58], is the possibility of exploiting a range of adsorbent materials to decrease the storage pressure of gaseous hydrogen. Solid-state hydrogen storage materials are generally grouped in two classes: metal hydrides, which store hy- 
drogen via chemical bond formation, and porous materials, which involve the physical adsorption of hydrogen [59]. The main research goal is to further minimize the weight of these materials, to compete with gaseous hydrogen storage. Current applications are still limited to specific cases for which the weight is not a critical parameter, such as stationary storage [60] or forklifts [61]. Further research is investigating the possibility of nanosizing different materials, with the aim of controlling the binding strength of hydrogen, thus avoiding high temperatures and pressures [59].

\subsection{Hydrogen Demand}

While most focus is put on the potential future energy demand, it is important to note that the current hydrogen demand worldwide has been rising for several decades. According to the IEA [5], global demand of hydrogen has increased from less than $30 \mathrm{Mt}$ of $\mathrm{H}_{2}$ in 1975 to $115 \mathrm{Mt}$ in 2018, including both hydrogen in pure form or mixed with other gases (with pure hydrogen summing up to more than $70 \mathrm{Mt}$ in 2018). The lion's share of the demand is related to industrial applications, mostly from oil refineries or chemicals production (ammonia and methanol).

A recent study focusing on the European Union [62] reports that the shift of the current hydrogen production towards green hydrogen generation is well below the renewable generation potential of all the countries that have been considered. The current EU hydrogen annual production of $9.75 \mathrm{Mt}$, if shifted to electrolysis, would require around $290 \mathrm{TWh}$ of electricity, which is about $10 \%$ of the total current production. However, hydrogen demand is expected to increase significantly in the future to decarbonize the energy system, and the RES scale-up that is required to support clean power generation may not be enough. For this reason, blue hydrogen is needed to fulfill hydrogen demand in a transition phase, since the RES scale-up will need to be dedicated to decarbonize the existing power demand [13].

\subsubsection{Industry}

Industry is virtually responsible for all the current global hydrogen consumption, and refineries and chemical industry are the most demanding sectors.

Hydrogen is currently used in refineries to reduce sulphur content in oil products to meet specific environmental standards, and in some cases to upgrade low-quality heavy oil. On a global scale, around one third of the demand is covered by hydrogen obtained as by-product of other refinery processes, while the remainder is locally produced via SMR or supplied by external producers [5]. In some cases, the cost of hydrogen can be significant when compared to the tight refining economic margins of last years. Existing hydrogen production facilities will likely remain the largest share of total future capacity in refineries, and it may be easier to integrate CCS in the current local SMR plants than deploy new electrolysis capacity. However, CCS facilities need to match specific conditions, which may not be available in some sites.

Hydrogen is also being used a feedstock for ammonia and methanol production. Ammonia production is primarily used for fertilizers, while methanol is used for a range of applications, including high-value chemicals for plastics or its blend with fuels to increase their performance. As of 2018, ammonia production consumed more than $30 \mathrm{Mt}$ of $\mathrm{H}_{2}$, and methanol around $12 \mathrm{Mt}$ [5]. The historical trends for these non-energy applications may lead to $42 \mathrm{Mt}$ and $23 \mathrm{Mt}$ by 2050, respectively. However, those figures are only considering current applications, and in the event of a larger use of ammonia and methanol as fuels, those quantities may significantly increase.

Another industrial application that relies on hydrogen is the steel production via the direct reduction of iron (DRI). This technique is currently limited to less than $10 \%$ of global primary steel production, but its share may increase in the future, due to the need to decarbonize all sectors, and if hydrogen costs decrease [63]. Current $\mathrm{H}_{2}$ consumption is generally produced on site, either from natural gas or coal. 
Future uses of hydrogen in industry could also extend to other applications, including the possibility of using it to generate high-temperature heat, where direct electrification is not an option.

\subsubsection{Transport}

While transportation currently accounts for a marginal share of global hydrogen demand, this sector is among the most promising for the development of hydrogen technologies, due to its heavy reliance on oil products and to the few low-carbon options in some applications.

One of the first segments in which hydrogen applications have been focused is passenger cars. In some countries there is already a market for hydrogen cars, including Japan, South Korea, the US (mostly in California) and Germany, as reported in Figure 4. The tenfold increase of the global hydrogen car fleet from 2015 to 2019, reaching almost 19,000 units, needs to be put into perspective by considering that the global battery electric car fleet reached 4.8 million units in 2019, up from around 17,000 electric cars on the roads in 2010 [64]. While some companies are selling hydrogen models in selected countries, battery electric vehicles are being chosen by an increasing number of car manufacturers worldwide.

\section{Hydrogen passenger cars stock per country}

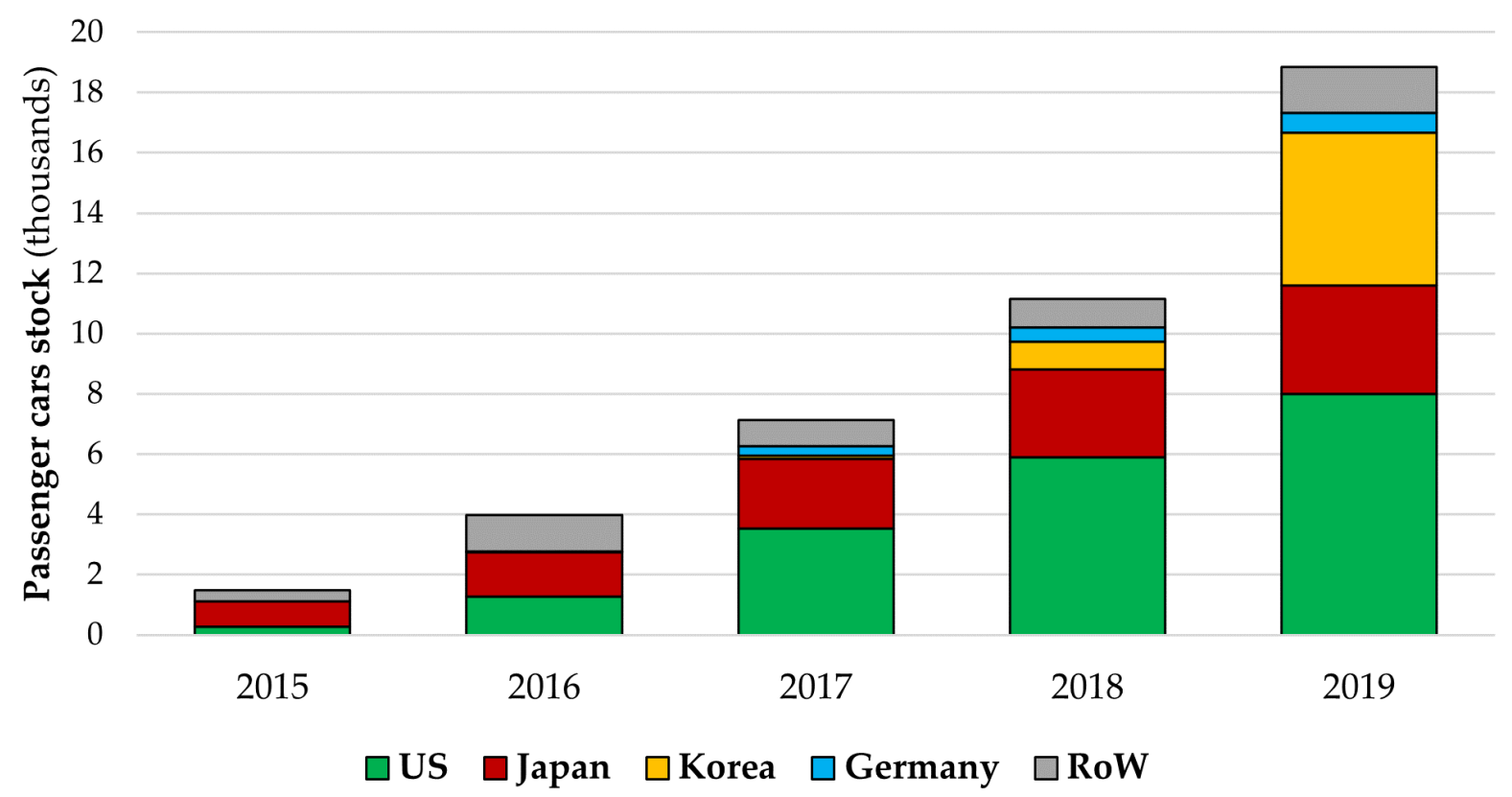

Figure 4. Hydrogen passenger cars stock in different countries. Authors' elaboration in References [64-66].

Hydrogen vehicles have specific advantages in comparison with electric vehicles, especially in the longer range and shorter refueling duration. The current high price of hydrogen is strongly hindering their development, and this is also a consequence of their lower efficiency than EVs when considering the entire supply chain. While an electric car can convert about three quarters of electricity towards useful energy, the same figure for an hydrogen car is as low as one third. Battery electric cars incur in losses for power transmission and storage, while hydrogen cars need additional components, including electrolyzers, hydrogen compression and storage, and on-board fuel cells. However, considering the potential uncertainties in the future development of alternative technologies, it may be early to choose a specific solution, all available options should be advanced alongside each other to avoid lock-in decisions [67]. 
In addition to private cars, some countries are also experimenting specific applications, such as taxi fleets. A notable example is the city of Paris, in which a hydrogen taxi fleet of 100 cars is already in operation, with a target of reaching 600 taxis by the end of 2020 [68]. A project under consultation by the European Network of Transmission System Operators for Electricity (ENTSO-E) aims at increasing this fleet to 50,000 taxis in Paris by 2030, as part of a billion euro investment to add 11 GWh of hydrogen storage capacity in the city [69].

A crucial step in deploying hydrogen cars, especially in high-density urban areas, is the availability of an effective network of refuelling stations [70]. The optimal planning of refueling stations location should be developed by considering the availability of hydrogen generation from different sources in the various phases of penetration. In particular, while in a first phase multiple countries may exploit a fossil-based hydrogen generation, the shift towards green hydrogen may impact the entire supply chain. Thus, it is important that the design of refueling stations is done with a medium and long-term perspective. In addition, the deployment of refuelling stations could also be coupled to specific applications, such as hydrogen-based car sharing systems [71].

The current advantages of hydrogen in comparison to batteries lead to a potential of this technology in road freight transportation, especially on long-haul operations. The advantages of hydrogen trucks in comparison with diesel have been demonstrated on a life-cycle perspective [72], but electricity consumption for compression and liquefaction has a significant weight in the final result. A possible short-term opportunity to gradually adopt hydrogen in road freight is to adopt dual fuel trucks by retrofitting existing fuel injection systems [73]. The expected emissions reductions are found to be proportional to the diesel displacement ratio. However, some experts estimate that the foreseen cost decreases in electric batteries will make them the standard low-carbon solution for trucks [74], possibly together with other technologies such as electric highways [75].

Industrial companies are gradually moving towards the test of hydrogen applications in trucks, but there are still no commercial models on the road. In parallel to the deployment of vehicles, it is important to guarantee the availability of a proper refuelling infrastructure. Hydrogen trucks are being tested in Norway [76] and in the Netherlands [77], and a German company is working to convert diesel heavy trucks to hydrogen hybrid drivetrains [78]. Additionally, initiatives are being deployed on a larger scale, such as the one in the port of Rotterdam aiming at reaching a thousand of fuel cell trucks on the road by 2025, involving several partners across the entire supply chain [79]. Their objective is to provide a hydrogen corridor across the Netherlands, Belgium and Germany. Other studies are also evaluating the benefits of hydrogen trucks in other world regions, such as China [80] and the Unites States [81].

In addition to private cars and freight transport, an application that has seen significant interest has been the development of hydrogen buses. Test cases have been performed in different countries (including Italy, Germany, Sweden, the UK [82,83], Japan and the US [84]), and hydrogen buses are a proven and reliable technology, although their economic sustainability is difficult to achieve with current hydrogen prices $[85,86]$.

Beyond road transportation, hydrogen can represent a potential solution also for trains, ships and planes. Fuel cells powered by hydrogen represent an interesting solution to power passenger and freight rail lines that are difficult to electrify due to technical or economic barriers. Refuelling infrastructure and vehicle design need to be carefully assessed by evaluating the operation schedules and the expected range, to optimize the performance of the system [87]. Commercial applications for regional passenger trains are seeing an increased interest in various European countries, including Germany [88], the UK [89], Italy [90] and France.

Hydrogen has also been proposed for a potential solution for the decarbonization of the shipping sector, although mostly through the use of ammonia, which would be easier to stock on ships in liquid form without the need of reaching very low temperatures [91]. Hydrogen is also being evaluated as a low-carbon solution for air transport, although highaltitude operation requires very though safety standard as well as high energy density [92]. 
Airbus has recently declared the ambition to build the first hydrogen-powered commercial aircraft by 2035, although so far only preliminary concepts have been presented [93].

\subsubsection{Buildings}

Some projects are considering potential hydrogen use in the buildings sector, either by blending hydrogen in natural gas grids, or developing dedicated hydrogen boilers. However, the applications to buildings' heating have lower advantages when compared to other low-carbon technologies, such as heat pumps (coupled to electricity from RES), except in very specific contexts.

Different studies have been performed to assess the behaviour of different technologies with rising volumetric concentrations of hydrogen in natural gas, including small-size boilers [94,95], industrial boilers, gas engines [96] and micro-turbines [97] for stationary power generation. Considering hydrogen-powered residential boilers, the most advanced applications are currently being tested in the Netherlands and the UK.

The UK has been the object of different studies to integrate hydrogen in the current energy infrastructure. The best known is probably the H21 Project [98], which started in 2016 by estimating the technical feasibility of converting the existing gas grid to carry $100 \%$ hydrogen in the city of Leeds. The UK government is currently supporting with 25 million pounds the Hy4Heat project [99], whose mission is "to establish if it is technically possible, safe and convenient to replace natural gas (methane) with hydrogen in residential and commercial buildings and gas appliances". In parallel, some companies are already proposing commercial boilers that can run on $100 \%$ hydrogen [100], targeting the potential applications that may not be easily decarbonized via heat pumps, due to technical barriers and limitations (including limited space, difficulty of insulating historical buildings and shifting towards low-temperature heating systems). However, while some demonstration sites are already being developed to test the technology [101], the deployment of an effective infrastructure to supply hydrogen to residential users may require some time, and the economic advantage over direct electric heating is not evident.

Another option for hydrogen use in buildings would be to exploit the high electric efficiency of fuel cells to power on-site combined heat and power (CHP) plants. Past studies were optimistic on the potential of exploiting hydrogen for micro-CHP [102], under the assumption of very low hydrogen costs and higher costs for other fuels. However, in the current situation the potential of micro-CHP in buildings appears less promising, also due to the little success that natural gas micro-CHP had shown, especially in the residential sector.

Finally, some researchers have proposed local hydrogen storage to guarantee the annual self-sufficiency of buildings equipped with photovoltaic (PV) systems, to compensate the seasonal output, although acknowledging the very high investment costs related to fuel cells and hydrogen storage system [103].

\subsubsection{Power Generation}

In addition to direct use in final sectors, hydrogen is also being considered to be used as dispatchable power generation. While the efficiency of electricity generation itself is usually high, either through fuel cells or adapted gas turbines and combined cycles, when considering the entire process including hydrogen production and storage, energy losses can be as high as $70 \%$. Economic sustainability could be guaranteed with electricity at zero or negative costs, but even in such a situation the annual operational hours should be high enough to justify the capital expenditures.

Nevertheless, to reach a fully decarbonized energy system, long-term electricity storage seems to be unavoidable, and hydrogen may be among the few available solutions. Additional investments in research are needed to decrease the full-cycle costs of electricity storage via hydrogen and support a more effective energy transition [104].

Climate strategies based on power generation from imported hydrogen have been proposed for regions with low local renewable potential, mostly in Japan $[105,106]$. Additional 
applications include the possibility of ensuring clean energy supply to remote locations such as mines, port cities or islands with low renewable potential, such as the Arctic region [107]. The use of electrolyzers and fuel cells coupled to variable renewable sources have been evaluated in multiple studies, to assess the feasibility of avoiding reliance on imported fossil fuels in remote islands or isolated micro-grids [108-110].

\section{Geopolitical Aspects}

The renewed interest on hydrogen have ignited several analyses on the potential geopolitical consequences caused by the development of hydrogen [12,111]. Numerous countries are taking into considerations the use of hydrogen-both blue and green-in hard-to-abate sectors in their efforts to reach their climate goals and full decarbonization by mid-century. Due to its high potential and multiple applications, hydrogen could also become a major geopolitical issue. The technological know-how is expected to become a more relevant issue of the energy geopolitics in the low-carbon future. Both countries and private companies are committed to gain the specific technological knowledge and competitiveness in order to become major players in the decarbonization effort.

As hydrogen technology takes ground, new "importers" and "exporters" will emerge. Meanwhile, fossil fuel producers and exporters are considering future hydrogen projects and plans in order to offset the potential geopolitical and economic loss caused by the energy transition. The aim of this section is to give a brief overview of the hydrogen geopolitical implications, presenting the main national hydrogen strategies, outlining potential hydrogen players, the role of private players in the hydrogen development projects and international agreements on hydrogen trade.

\subsection{National Strategies}

A growing number of countries have released or been working on national hydrogen strategies aiming at developing hydrogen technologies and markets [11]. Such strategies reflect the different ambitions and energy needs of countries as well as the potential division between "importers" and "exporters". As outlined in a recent IRENA paper [112], national strategies are only the last step of a longer process. Indeed, countries initially establish R\&D programmes to understand the fundamentals of the hydrogen technology, to move to a long-term 'vision' document. A further step is a 'roadmap' that defines an integrated plan with the activities needed to better assess the potential for hydrogen. A roadmap identifies the short- and mid-term actions needed to advance the hydrogen deployment, defining the highest priorities in the research areas. The final step is the strategy defines the targets, addressing concrete policies and evaluates their coherence with existing energy policy.

Currently, Asia and Europe are the two continents that dominate the hydrogen demand creation.

Japan is the main frontrunner in the hydrogen economy. In December 2017, Japan presented its hydrogen strategy. Moreover, in 2019 Japan updated its Strategic Road Map for Hydrogen and Fuel Cells. Currently, Japan is heavily dependent on energy imports, mostly fossil fuels. In 2019, Japan was the fourth-largest crude oil importer, top LNG importer and the third-largest importer of coal. This condition has been exacerbated by the closure of Japan's nuclear plans following the 2011 Fukushima nuclear accident. Following the nuclear accident, Japan energy mix and power generation has mutated substantially. Natural gas, oil and renewable energy increased their shares of total energy consumption to replace the nuclear share. Although Japan decided to reopen some of its nuclear plants, fossil fuels contribute to over 87 per cent of Japan's primary energy supply, undermining its national climate target. Thus, hydrogen could provide a viable solution to implement its climate targets (i.e., carbon-neutrality by 2050).

In Japan, much budget has been spent on fuel cells research in the last decades, although with little impact on the actual deployment of commercial applications [113]. In contrast, little focus has been put on other steps of the supply chain, resulting in low national expertise on generation and supply. Japan's extremely high import dependency (the 
country is importing all its oil and gas needs) will not vanish, as it plans to import most of its hydrogen. Japan did not announce clearly its preference for a specific hydrogen pathway.

Other countries are focusing their strategies in specific sectors. For example, China has developed its hydrogen strategy in the transport sector [114], including the implementation of dedicated incentives to foster the adoption of fuel cell vehicles.

In 2020, China announced its plan to reach carbon-neutrality by 2060. In this effort, nuclear could gain more relevance in the Chinese energy mix. China is currently building or planning more than fifty new nuclear reactors. The nuclear sector could become an additional source of hydrogen in the endeavour to offset nuclear's high economic costs and develop clean hydrogen.

Currently, China is the world's largest hydrogen producer-over 20 million tons per year corresponding to almost one-third of the world's total production. Nevertheless, most of China's hydrogen comes from coal. The China Hydrogen Alliance expects hydrogen demand to increase by 35 million tons in 2030 and green hydrogen to account for 15 per cent of total domestic demand. In 2040, hydrogen demand is expected to increase to 45 million tons (with green hydrogen accounting for 40 per cent), and in 2050 to 60 million tons (green hydrogen accounting for 75 per cent) [115].

Another Asian country that launched a hydrogen strategy is South Korea. At the beginning of 2019, South Korea announced its Hydrogen Economy Roadmap. Its priorities are the leadership in fuel cells for cars and large scale stationary fuel cells for power, given also the strong role of the Korean automotive sector. The Roadmap aims to produce 6.2 million FCEVs by 2040. Of this figure, 2.9 million units should be devoted to the domestic market, while 3.3 million for export. Moreover, the roadmap outlines to supply $15 \mathrm{GW}$ of fuel cells for power generation by 2040, including $7 \mathrm{GW}$ for export [116].

In Europe, hydrogen has drawn a special interest both at the European and the national level. In July 2020, the European Union has published its hydrogen strategy. The EU strategy sets green hydrogen as the European top priority, while blue hydrogen is seen only as a temporary solution for the medium term. By 2030, the EU is committed to have $40 \mathrm{GW}$ of hydrogen electrolyzer capacity - to put it into perspective-almost twice the capacity of China's Three Gorges Dam, the world's largest power plant. To achieve this goal, the EU envisages as much as EUR 470 billion of public and private investments by 2050. Moreover, throughout the same period, it announced the construction of an import supply chain with an additional $40 \mathrm{GW}$ from Eastern and Southern neighboring countries (i.e., Ukraine and North African countries).

In parallel, some European Member States have released their own hydrogen strategies. Among them, Spain, Germany and France announced their commitment to install 4, 5, and $6.5 \mathrm{GW}$ of green hydrogen by 2030, respectively [117]. Green hydrogen national targets of Germany, France, Portugal, the Netherlands and Spain already account for more than 50 per cent of the EU's targeted $40 \mathrm{GW}$ of installed electrolyzer capacity in 2030. These countries announced multi-billion investments on hydrogen. In the aftermath of COVID-19 and economic slowdown, governments might consider to allocate funds to hydrogen as a viable way to foster economic recovery while implementing climate targets.

Different potential hydrogen importers rely on different hydrogen strategies. While Europe has clearly announced its preference for green hydrogen, Asian markets (i.e., South Korea, Japan, and China) have a more diversified grey-blue-green strategy for upcoming decades.

While most countries have developed hydrogen strategies driven by domestic decarbonization targets, others are starting to focus on low-carbon hydrogen as a potential resource to be exported.

Countries that rely on oil and gas exports for government revenues are particularly interested to develop hydrogen for export.

A notable example is Australia, which is developing several projects aiming at becoming a world-class exporter. Given its geographical location and large resource availability, Australia seeks to supply clean hydrogen to Asian markets, especially Japan and Korea. 
In February 2020, Australia's Energy and Emissions Reduction Minister announced an ambitious "H2 under 2" target, aiming at cutting hydrogen production costs to less than 2 AUD per $\mathrm{kg}$ (i.e., 1.5 USD per $\mathrm{kg}$ ). This challenging goal will need supportive policies coordinated with industrial strategies and research activities [118].

Major oil and gas producers of the Middle East and North Africa (MENA) region are increasingly evaluating hydrogen projects and plans. These countries are the cornerstone of the existing global energy system-based on fossil fuels. Fossil fuels—especially oil—are the main government and export revenue sources for many of these countries. Therefore, the global energy transition, with the rising role of RES, poses an existential threat to their domestic stability. These countries are considering ways to offset the negative macroeconomic effects and reduced geopolitical role in a future decarbonized world. Given their abundant renewable and CCS potential, MENA oil and gas producers could position themselves as leading exporting countries of green hydrogen. Despite the great potential, MENA countries' hydrogen ambitions could be undermined by the high water scarcity in the region. It is expected that MENA water stress will only worsen due to climate change. To address their water deficit, the MENA countries could develop hydrogen projects along with desalination plans as in Neom. That would further develop MENA's desalination capacity, which currently accounts for almost half of the global desalination capacity.

As of today, three Gulf countries have announced hydrogen projects: Saudi Arabia, the United Arab Emirates (UAE) and Oman. In July 2020, Air Products, Saudi ACWA and Neom signed a joint-venture agreement to develop a USD 5 billion green hydrogen and green ammonia plant (considered the largest in the world) powered by solar and wind energy. The project should come online in 2025 . The plant will be powered through the integration of more than $4 \mathrm{GW}$ of renewable power from solar and wind [119]. Although it could position Saudi Arabia as a top green hydrogen exporter, the project faces serious challenges. The announced renewable capacity that would power the hydrogen plan is significant. Moreover, the project will require major financial support, albeit the Saudi macroeconomic and financial constrains caused by the oil price drop in 2020.

The UAE is investing in green and blue hydrogen projects in the effort to develop new clean energy sources. Although the UAE is still working on its official hydrogen roadmap, state-owned Dubai Electricity and Water Authority (DEWA) is committed to develop a green hydrogen mobility project, taking advantage of the solar-driven electrolysis facility at the Mohammed bin Rashid Al Maktoum Solar Park. The solar park is expected to have an installed capacity of $5 \mathrm{GW}$ by 2030 . The UAE is confident that competitive prices from solar power will be an enabler to reduce green hydrogen prices [120]. Despite its ambitions on renewables, the UAE is also looking at blue hydrogen capitalizing its CCUS potential.

Oman is the third Gulf country that has been studying the potential for domestic use of hydrogen. To do so, Oman announced the construction of a green hydrogen plant at the Duqm port, where a large export-focused refinery and petrochemicals facility are being developed. The Hyport Duqm facility is expected to have an electrolyzer capacity of 250-500 MW from the first phase, with products earmarked for exports. The state-owned Petroleum Development Oman is looking to attract investment also from Asian countries, notably Japan, suggesting that a portion of future output would likely be destined for exports to Asia. Oman announced an upcoming hydrogen strategy.

Another MENA country that plans to become an important hydrogen exporter is Morocco. Morocco does not hold any known hydrocarbon reserves, but seeks to exploit its great solar and wind potential in order to develop hydrogen. Morocco already has invested importantly in renewable energy (wind, solar PV and concentrated solar power) in order to lessen its high import dependency. By 2030, the country aims to produce 52 per cent of its electricity from renewable sources, which corresponds to around $11 \mathrm{GW}$ of installed renewable power [121]. The ambition is to devote one-third of Morocco's green hydrogen to the domestic market, while two-thirds to exports. Given its vast solar and wind resources and its proximity to Europe, Morocco could become a key source of green 
hydrogen to Europe. The close ties with Germany are an example of the future geopolitical landscape, as outlined in Section 3.3.

As European decarbonization unfolds, Russia is another major oil and gas exporter that will need to consider potential hydrogen projects in order to preserve its revenues and geopolitical influence. Russia could benefit of its major natural gas reserves to become a major player in the hydrogen economy. In November 2020, Russian Deputy Minister of Energy Pavel Sorokin unveiled a new government policy to export 200,000 tons of hydrogen a year by 2024, increasing it to 2 million tons by 2035 [122]. Russia could also benefit from its nuclear capacity to produce hydrogen. Besides its gas and nuclear potential, large reserves of fresh water and its geostrategic location between Europe and Asia could further contribute to position Russia as a leading hydrogen player.

Furthermore, other possible green hydrogen exporters are emerging across the world. Chile is one of them. The South American country, already a major supplier of minerals, has the potential to export green hydrogen, producing 25 million tons per year of green hydrogen by 2050. The clean hydrogen exports could provide significant revenues, estimated to be more than USD 30 billion [11]. Given its geographical location, Chile could become a major player in the hydrogen trade, delivering clean energy to Asian markets (Korea, Japan and potentially also China) in addition to North America and Western Europe.

Finally, national hydrogen strategies reflect the potential role that each country could play. Domestic consumption and renewable production potential are only some of the main factors that will define future 'importers' and 'exporters', as Figure 5 illustrates.

Green hydrogen domestic consumption and production potential

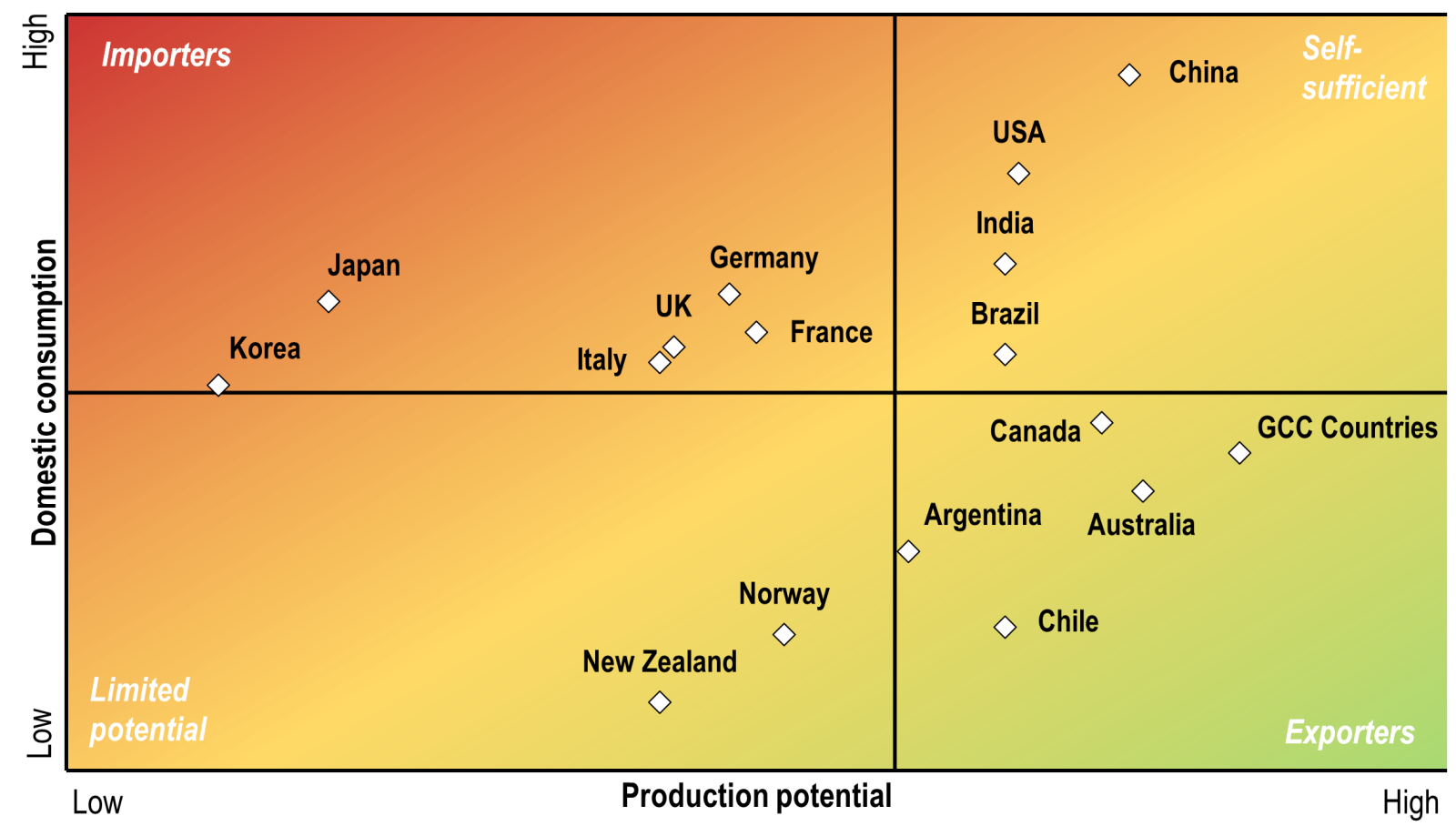

Figure 5. Comparison of selected countries based on green hydrogen domestic consumption and production potential. GCC means Gulf Cooperation Council (including Bahrain, Kuwait, Oman, Qatar, Saudi Arabia, and the United Arab Emirates). Source: [123].

\subsection{The Role of Private Companies}

Hydrogen has raised interest not only from national governments but also from the private sector. 
Firstly, international oil companies (IOCs) have started to consider potential hydrogen projects in light of their climate commitments and increasing political pressure. It is important to note a general trend among IOCs: the increasingly divergence between European and US energy majors. While European IOCs have invested increasingly in renewable energy sources, US IOCs continue to focus on traditional fossil fuel assets.

In February 2020, NortH2 was launched by a consortium composed of Shell, Gasunie and Groningen Seaports. The project aims to produce green hydrogen using renewable electricity generated by a mega offshore farm in the North Sea. The project will have a capacity of $1 \mathrm{GW}$ in 2027, $4 \mathrm{GW}$ by 2030 and it has the ambition to grow to about $10 \mathrm{GW}$ by 2040. This project gained the support of Equinor and RWE, which became new partners in December 2020. By 2021, the project will complete a feasibility study, with the aim to start project development activities in the second half of 2021.

In November 2020, BP started to work together with Ørsted to develop a project, Lingen Green Hydrogen, for industrial-scale production of green hydrogen. Under this project, the two companies aims to build an initial $50 \mathrm{MW}$ electrolyzer and the associated infrastructure at BP's Lingen Refinery in north-west Germany. This will be powered by renewable energy generated by an Ørsted offshore wind farm in the North Sea and the hydrogen produced will be used in the refinery. BP and Ørsted plan to make a final investment decision (FID) by early 2022 and the project could be operational by 2024 .

Also Spain's largest energy company, Repsol, is scaling up investments in hydrogen. It will invest EUR 60 million to build a plant in Spain that creates ultralow-emission fuels by combining green hydrogen from wind power with CCS at a nearby Petronor refinery.

Secondly, electricity utilities are particularly keen to invest in hydrogen. They are pushing for green hydrogen both at home and abroad. An example is Italy's Enel, which is planning to build the first project to produce green hydrogen in Chile. The project will be powered by wind energy and it could enter production by 2022. Other major utilities, like Spain's Iberdrola, the US NextEra and Germany's Uniper, have launched hydrogen projects. Electricity utilities are increasingly gaining relevance, as electrification and decarbonization gain ground. Hydrogen provides them an additional field to enhance their role as major energy players of the decarbonization.

Thirdly, gas grid operators might see a reduction of revenues and influence due to the growth of renewable energy sources. Hydrogen provides them the chance to be part of climate efforts. Gas grid operators have proposed to convert the existing gas pipelines to transport hydrogen. Although there are some challenges to the use of hydrogen in the gas pipelines, European gas grid operators released a plan (the so-called "European Hydrogen Backbone") in July 2020 [124], presenting an infrastructural network emerging from the mid-2020s onwards. By 2030, an initial pipeline network of $6800 \mathrm{~km}$ would be limited to selected hydrogen valleys, whereas by 2040 that network would enlarge to almost $23,000 \mathrm{~km}$, stretching through the entire continent. Gas grid operators, like Italy's Snam, are betting on hydrogen in an effort to be part of the decarbonization process with their infrastructure and avoid potential stranded assets. In 2020, Snam committed to a plan to invest EUR 7.4 billion over the next four years. Snam is committed to devote 50 per cent of that total to create a "hydrogen-ready" infrastructure, or the replacement and development of new assets with hydrogen-ready standards. Snam believes that Italy is well-positioned to become a hydrogen hub for European markets, importing green and blue hydrogen from the North African countries.

The development of an affordable hydrogen economy faces major challenges. Therefore, numerous companies-across different sectors-have started to coordinate their efforts. An example is the Green Hydrogen Catapult initiative, which was founded by seven companies: Spain's Iberdrola, Denmark's Orsted, Italy's Snam, Saudi Arabia's ACWA, CWP Renewables and Yara. The Green Hydrogen Catapult aims to develop up to $25 \mathrm{GW}$ of worldwide renewables-based hydrogen production capacity and halve the current production costs to below USD $2 / \mathrm{kg}$ by 2026 . This target will require an investment of roughly USD 110 billion [125]. 


\subsection{International Agreements}

Hydrogen may redraw future international energy trades. Indeed, in parallel with national hydrogen strategies, some countries are already setting up dedicated bilateral agreements to couple countries with high production potential with countries with high hydrogen demand.

Among the potential importers, Germany is working with Morocco to support the production of green hydrogen in the country, with the first $100 \mathrm{MW}$ project powered with solar energy. In September 2020, Germany also signed a bilateral agreement with Australia aiming at increasing imports of hydrogen production with solar power plants in Australia.

Among potential exporters, Australia is the front-runner. With its recent agreement with Germany, Australia has taken another step forward in its ambition to become a powerhouse in hydrogen production and exports. As mentioned before, Australia is also looking to export its hydrogen to the fast-growing Asian energy markets. The partnership with Germany comes in addition to existing commitments Australia has already sought with other countries including Japan, South Korea and Singapore. In September 2020, the world's first blue ammonia shipment from Saudi Arabia to Japan set an important milestone in the future trade of ammonia as an energy vector. The first blue ammonia cargo of $40 \mathrm{t}$ shipped to Japan was used for power generation [126]. Japan announced that ammonia will play an important role in Japan's thermal power generation, as part of Japanese efforts to achieve carbon neutrality in 2050.

\section{Conclusions and Policy Recommendations}

There is currently significant momentum towards the development of future hydrogen strategies across the world. This paper has presented the main aspects related to the implementation of an energy system based on hydrogen technologies, as well as market and geopolitical perspectives related to hydrogen generation, either via green or blue pathways, its transport, storage and final use in different sectors.

The success of a future hydrogen economy will require to tackle multiple aspects, by improving the current technologies to supply hydrogen to interested users at a competitive cost. The objective is not the use of hydrogen itself, but a transition of the current energy system towards low-carbon alternatives. Thus, hydrogen is a key component of a broader picture, and it is important that future strategies for its implementation are well integrated with other solutions.

In this perspective, the comparison of green and blue hydrogen pathways should be addressed by considering the potential contribution of both solutions to support a low-carbon energy system. In many countries the scaling up of RES power capacity may not be enough to support the low-carbon hydrogen demand, and blue hydrogen may be used to fill this gap during the transition.

In addition to hydrogen generation, it is important to consider its entire value chain. While most technologies are already mature at different levels of the hydrogen supply chain, its complexity causes a relatively low energy efficiency, due to the numerous processes that are needed to supply hydrogen to final users. The focus is often on the generation costs, but evidence shows that both hydrogen transportation and storage represent key challenges in terms of energy losses and required infrastructure. The success in addressing technical limitations, and in deploying clear and coherent strategies, will be two key aspects in reaching acceptable costs for low-carbon hydrogen.

Nevertheless, the complexity of the hydrogen supply chain suggests that hydrogen is a valuable carrier that should be used primarily in applications that have few feasible alternatives for decarbonization. This is usually reflected in prices, since the lower the possibility of substituting a resource with other alternatives, the higher its price.

Since climate change is a global problem, an effective strategy requires strong international agreements, to fully acknowledge and quantify the potential benefits in terms of GHG emission reductions [127]. In particular, it is important to define transparent and clear standards and targets for the development of hydrogen pathways and expected 
impacts, including the technologies that are considered, the system boundaries (either system operation or including lifecycle assessments) and the thresholds that are assumed to define low-carbon hydrogen. Without a clear alignment across countries, there is the risk that different visions overlap each other, and may not lead to an optimal deployment of the available resources. Moreover, it is crucial to avoid setting final targets, without a serious presentation of a realistic timeline and intermediate targets. To do so, policies and roadmaps need to take into account uncertainties and challenges, and regularly adapt to new knowledge and realities.

Hydrogen could draw a new geopolitical map. Also in the hydrogen geopolitics, countries will consider classic energy geopolitical issues, such as security of supply/demand and diversification. Geopolitics will increasingly take into account technological dominance, along with resource availability. Current oil and gas major producers will, along with other countries endowed with RES, try to position themselves as secure and reliable hydrogen exporters, in order to preserve or gain a geopolitical role (as well as the consequent revenues). Some countries or regions will need to import hydrogen (green and/or blue) to meet their climate targets, in addition to producing part of their hydrogen needs domestically.

An international hydrogen trade is emerging. Although hydrogen can contribute to cut emissions and decarbonize hard-to-abate sectors in some regions, it should not be forgotten that all countries should focus on providing clean energy to their citizens. Therefore, governments and companies should cooperate in order to prevent a situation whereby green hydrogen is exported while local energy needs are partially satisfied with more polluting energy sources.

While the primary driver for hydrogen development is the decarbonization of the energy system, it is important to consider additional impacts that are often overlooked, including the need of fresh water to produce both green and blue hydrogen-although with different specific water demands. Indeed, even though certain solutions, such as seawater desalination or wastewater reuse, may help in tackling this critical issue, a comprehensive analysis is needed to avoid negative impacts on local ecosystems and limitations to freshwater availability for other uses.

The authors believe that the development of low-carbon hydrogen pathways, just like for other technologies aiming at fighting climate change, should be supported by clear visions based on a global perspective. National strategies may have little effect without a broader focus on the global picture, since they risk to widen the gap across countries and worsen existing inequalities. In such a divided world, reaching the challenging targets required to limit climate change will be an even harder task.

Author Contributions: M.N., P.P.R., R.S. and M.H. have conceptualized together the study, and they have contributed at different degrees to all the sections of the work. M.N. is the leading author on the technological section, and P.P.R. on the geopolitical section. M.N., P.P.R., R.S. and M.H. have contributed to the writing and review of the final paper. All authors have read and agreed to the published version of the manuscript.

Funding: This research received no external funding.

Institutional Review Board Statement: Not applicable.

Informed Consent Statement: Not applicable.

Data Availability Statement: No new data were created or analyzed in this study. Data sharing is not applicable to this article.

Conflicts of Interest: The authors declare no conflict of interest. 


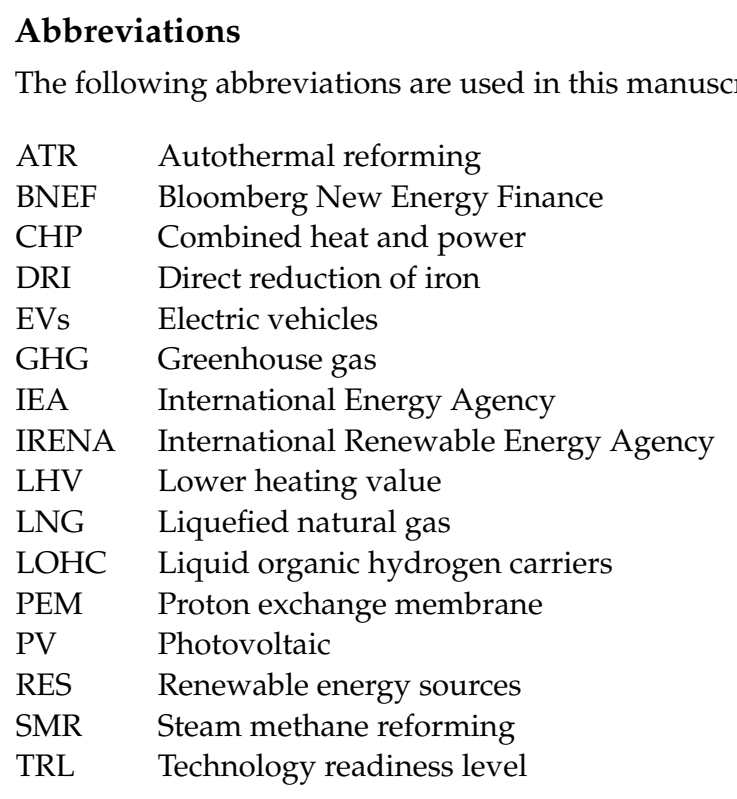

\section{References}

1. Chaube, A.; Chapman, A.; Shigetomi, Y.; Huff, K.; Stubbins, J. The Role of Hydrogen in Achieving Long Term Japanese Energy System Goals. Energies 2020, 13, 4539. [CrossRef]

2. German Federal Government-Federal Ministry for Economic Affairs and Energy. The National Hydrogen Strategy. 2020. Available online: https://www.bmwi.de/Redaktion/EN/Publikationen/Energie/the-national-hydrogen-strategy.pdf (accessed on 18 December 2020).

3. Australian Government. Australia's National Hydrogen Strategy. 2019. Available online: https://www.industry.gov.au/dataand-publications/australias-national-hydrogen-strategy (accessed on 18 December 2020).

4. EU Commission. A Hydrogen Strategy for a Climate Neutral Europe. 2020. Available online: https://ec.europa.eu/commission/ presscorner/detail/en/FS_20_1296 (accessed on 18 December 2020).

5. IEA. The Future of Hydrogen. 2019. Available online: https://www.iea.org/reports/the-future-of-hydrogen (accessed on 10 December 2020).

6. Bloomberg. Bloomberg: A Three-Part Series on Hydrogen Energy. 2020. Available online: https://www.bloomberg.com/graphics/20 20-opinion-hydrogen-green-energy-revolution-challenges-risks-advantages/oil.html (accessed on 11 December 2020).

7. Rifkin, J. The Hydrogen Economy; Tarcher-Putnam: New York, NY, USA, 2002.

8. IRENA. Hydrogen: A Renewable Energy Perspective. 2019. Available online: https://www.irena.org/-/media/Files/IRENA/ Agency/Publication/2019/Sep/IRENA_Hydrogen_2019.pdf (accessed on 18 December 2020).

9. Newborough, M.; Cooley, G. Developments in the global hydrogen market: The spectrum of hydrogen colours. Fuel Cells Bull. 2020, 2020, 16-22. [CrossRef]

10. Ivanenko, A. A Look At The Colors Of Hydrogen That Could Power Our Future. Forbes, 2020. Available online: https:/ / www.forbes.com/sites/forbestechcouncil/2020/08/31/a-look-at-the-colors-of-hydrogen-that-could-power-ourfuture/?sh=3edf9d6e5e91 (accessed on 30 December 2020).

11. Scita, R.; Raimondi, P.P.; Noussan, M. Green Hydrogen: The Holy Grail of Decarbonisation? An Analysis of the Technical and Geopolitical Impilcations of the Future Hydrogen Economy; FEEM Nota di Lavoro; Fondazione Eni Enrico Mattei, Milano, Italy; 2020 ; Volume 2020.

12. Van de Graaf, T.; Overland, I.; Scholten, D.; Westphal, K. The new oil? The geopolitics and international governance of hydrogen. Energy Res. Soc. Sci. 2020, 70, 101667. [CrossRef]

13. Dickel, R. Blue Hydrogen as an Enabler of Green Hydrogen: The Case of Germany; OIES Paper; The Oxford Institute for Energy Studies: Oxford, UK, 2020.

14. BloombergNEF. Hydrogen Economy Outlook. 2020. Available online: https://data.bloomberglp.com/professional/sites/24 /BNEF-Hydrogen-Economy-Outlook-Key-Messages-30-Mar-2020.pdf (accessed on 18 December 2020).

15. El-Emam, R.S.; Ozcan, H.; Zamfirescu, C. Updates on promising thermochemical cycles for clean hydrogen production using nuclear energy. J. Clean. Prod. 2020, 262, 121424. [CrossRef]

16. Pinsky, R.; Sabharwall, P.; Hartvigsen, J.; O’Brien, J. Comparative review of hydrogen production technologies for nuclear hybrid energy systems. Prog. Nucl. Energy 2020, 123, 103317. [CrossRef]

17. Ping, Z.; Laijun, W.; Songzhe, C.; Jingming, X. Progress of nuclear hydrogen production through the iodine-sulfur process in China. Renew. Sustain. Energy Rev. 2018, 81, 1802-1812. [CrossRef]

18. Zhiznin, S.; Timokhov, V.; Gusev, A. Economic aspects of nuclear and hydrogen energy in the world and Russia. Int. J. Hydrog. Energy 2020, 45, 31353-31366. [CrossRef] 
19. Bhandari, R.; Trudewind, C.A.; Zapp, P. Life cycle assessment of hydrogen production via electrolysis-A review. J. Clean. Prod. 2014, 85, 151-163. [CrossRef]

20. IRENA. Hydrogen from Renewable Power-Technology Outlook for the Energy Transition. 2018. Available online: https://www. irena.org/- / media/Files/IRENA/Agency/Publication/2018/Sep/IRENA_Hydrogen_from_renewable_power_2018.pdf (accessed on 10 December 2020).

21. IEA. Global Electrolysis Capacity Becoming Operational Annually, 2014-2023. Historical And Announced. 2020. Available online: https: / / www.iea.org/data-and-statistics/charts/global-electrolysis-capacity-becoming-operational-annually-2014-2 023-historical-and-announced (accessed on 10 December 2020).

22. Thomas, D. Renewable Hydrogen-The Missing Link between the Power, Gas, Industry and Transport Sectors. 2018. Available online: https:/ / hydrogeneurope.eu/sites/default/files/2018-06/2018-06_Hydrogenics_Company\%20presentation.compressed. pdf (accessed on 10 December 2020).

23. Al-Qahtani, A.; Parkinson, B.; Hellgardt, K.; Shah, N.; Guillen-Gosalbez, G. Uncovering the true cost of hydrogen production routes using life cycle monetisation. Appl. Energy 2021, 281, 115958. [CrossRef]

24. d'Amore Domenech, R.; Santiago, Ó.; Leo, T.J. Multicriteria analysis of seawater electrolysis technologies for green hydrogen production at sea. Renew. Sustain. Energy Rev. 2020, 133, 110166. [CrossRef]

25. Cloete, S.; Ruhnau, O.; Hirth, L. On capital utilization in the hydrogen economy: The quest to minimize idle capacity in renewables-rich energy systems. Int. J. Hydrog. Energy 2020, 46, 169-188. [CrossRef]

26. Rabiee, A.; Keane, A.; Soroudi, A. Technical barriers for harnessing the green hydrogen: A power system perspective. Renew. Energy 2021, 163, 1580-1587. [CrossRef]

27. Proost, J. Critical assessment of the production scale required for fossil parity of green electrolytic hydrogen. Int. J. Hydrog. Energy 2020, 45, 17067-17075. [CrossRef]

28. Armijo, J.; Philibert, C. Flexible production of green hydrogen and ammonia from variable solar and wind energy: Case study of Chile and Argentina. Int. J. Hydrog. Energy 2020, 45, 1541-1558. [CrossRef]

29. The Royal Society. Options foR Producing Low-Carbon Hydrogen at Scale. 2018. Available online: https://royalsociety.org/ / media/policy/projects/hydrogen-production/energy-briefing-green-hydrogen.pdf (accessed on 10 December 2020).

30. CertifHy. CertifHy-SD Hydrogen Criteria. 2019. Available online: https://www.certifhy.eu/images/media/files/CertifHy_2 deliverables/CertifHy_H2-criteria-definition_V1-1_2019-03-13_clean_endorsed.pdf (accessed on 18 December 2020).

31. Philibert, C. Methane Splitting and Turquoise Ammonia. 2020. Available online: https://www.ammoniaenergy.org/articles/ methane-splitting-and-turquoise-ammonia/ (accessed on 10 December 2020).

32. Fuel Cells Bulletin. German, French TSOs in MOU on transport, blending of hydrogen in natural gas networks. Fuel Cells Bull. 2020, 2020, 10. [CrossRef]

33. Pellegrini, M.; Guzzini, A.; Saccani, C. A Preliminary Assessment of the Potential of Low Percentage Green Hydrogen Blending in the Italian Natural Gas Network. Energies 2020, 13, 5570. [CrossRef]

34. Ekhtiari, A.; Flynn, D.; Syron, E. Investigation of the Multi-Point Injection of Green Hydrogen from Curtailed Renewable Power into a Gas Network. Energies 2020, 13, 6047. [CrossRef]

35. Cerniauskas, S.; Jose Chavez Junco, A.; Grube, T.; Robinius, M.; Stolten, D. Options of natural gas pipeline reassignment for hydrogen: Cost assessment for a Germany case study. Int. J. Hydrog. Energy 2020, 45, 12095-12107. [CrossRef]

36. Nguyen, T.T.; Park, J.S.; Kim, W.S.; Nahm, S.H.; Beak, U.B. Environment hydrogen embrittlement of pipeline steel X70 under various gas mixture conditions with in situ small punch tests. Mater. Sci. Eng. A 2020, 781, 139114. [CrossRef]

37. Wulf, C.; Reuß, M.; Grube, T.; Zapp, P.; Robinius, M.; Hake, J.F.; Stolten, D. Life Cycle Assessment of hydrogen transport and distribution options. J. Clean. Prod. 2018, 199, 431-443. [CrossRef]

38. Ishimoto, Y.; Voldsund, M.; Nekså, P.; Roussanaly, S.; Berstad, D.; Gardarsdottir, S.O. Large-scale production and transport of hydrogen from Norway to Europe and Japan: Value chain analysis and comparison of liquid hydrogen and ammonia as energy carriers. Int. J. Hydrog. Energy 2020, 45, 32865-32883. [CrossRef]

39. Boretti, A. Production of hydrogen for export from wind and solar energy, natural gas, and coal in Australia. Int. J. Hydrog. Energy 2020, 45, 3899-3904. [CrossRef]

40. Gallardo, F.I.; Monforti Ferrario, A.; Lamagna, M.; Bocci, E.; Astiaso Garcia, D.; Baeza-Jeria, T.E. A Techno-Economic Analysis of solar hydrogen production by electrolysis in the north of Chile and the case of exportation from Atacama Desert to Japan. Int. J. Hydrog. Energy 2020, in press. [CrossRef]

41. Heuser, P.M.; Ryberg, D.S.; Grube, T.; Robinius, M.; Stolten, D. Techno-economic analysis of a potential energy trading link between Patagonia and Japan based on $\mathrm{CO}_{2}$ free hydrogen. Int. J. Hydrog. Energy 2019, 44, 12733-12747. [CrossRef]

42. Ash, N.; Scarbrough, T. Sailing on Solar: Could Green Ammonia Decarbonise International Shipping? Environmental Defense Fund: London, UK, 2019.

43. Miyaoka, H.; Miyaoka, H.; Ichikawa, T.; Ichikawa, T.; Kojima, Y. Highly purified hydrogen production from ammonia for PEM fuel cell. Int. J. Hydrog. Energy 2018, 43, 14486-14492. [CrossRef]

44. Reuß, M.; Grube, T.; Robinius, M.; Stolten, D. A hydrogen supply chain with spatial resolution: Comparative analysis of infrastructure technologies in Germany. Appl. Energy 2019, 247, 438-453. [CrossRef] 
45. Tlili, O.; Mansilla, C.; Linßen, J.; Reuß, M.; Grube, T.; Robinius, M.; André, J.; Perez, Y.; Le Duigou, A.; Stolten, D. Geospatial modelling of the hydrogen infrastructure in France in order to identify the most suited supply chains. Int. J. Hydrog. Energy 2020, 45, 3053-3072. [CrossRef]

46. Lahnaoui, A.; Wulf, C.; Heinrichs, H.; Dalmazzone, D. Optimizing hydrogen transportation system for mobility via compressed hydrogen trucks. Int. J. Hydrog. Energy 2019, 44, 19302-19312. [CrossRef]

47. Moradi, R.; Groth, K.M. Hydrogen storage and delivery: Review of the state of the art technologies and risk and reliability analysis. Int. J. Hydrog. Energy 2019, 44, 12254-12269. [CrossRef]

48. Bracha, M.; Lorenz, G.; Patzelt, A.; Wanner, M. Large-scale hydrogen liquefaction in Germany. Int. J. Hydrog. Energy 1994, 19, 53-59. [CrossRef]

49. Wijayanta, A.T.; Oda, T.; Purnomo, C.W.; Kashiwagi, T.; Aziz, M. Liquid hydrogen, methylcyclohexane, and ammonia as potential hydrogen storage: Comparison review. Int. J. Hydrog. Energy 2019, 44, 15026-15044. [CrossRef]

50. Aakko-Saksa, P.T.; Cook, C.; Kiviaho, J.; Repo, T. Liquid organic hydrogen carriers for transportation and storing of renewable energy-Review and discussion. J. Power Sources 2018, 396, 803-823. [CrossRef]

51. Brey, J. Use of hydrogen as a seasonal energy storage system to manage renewable power deployment in Spain by 2030 . Int. J. Hydrog. Energy 2020, in press. [CrossRef]

52. Reuß, M.; Grube, T.; Robinius, M.; Preuster, P.; Wasserscheid, P.; Stolten, D. Seasonal storage and alternative carriers: A flexible hydrogen supply chain model. Appl. Energy 2017, 200, 290-302. [CrossRef]

53. Zivar, D.; Kumar, S.; Foroozesh, J. Underground hydrogen storage: A comprehensive review. Int. J. Hydrog. Energy 2020, in press. [CrossRef]

54. Caglayan, D.G.; Weber, N.; Heinrichs, H.U.; Linßen, J.; Robinius, M.; Kukla, P.A.; Stolten, D. Technical potential of salt caverns for hydrogen storage in Europe. Int. J. Hydrog. Energy 2020, 45, 6793-6805. [CrossRef]

55. Tarkowski, R. Perspectives of using the geological subsurface for hydrogen storage in Poland. Int. J. Hydrog. Energy 2017, 42, 347-355. [CrossRef]

56. Bai, M.; Song, K.; Sun, Y.; He, M.; Li, Y.; Sun, J. An overview of hydrogen underground storage technology and prospects in China. J. Pet. Sci. Eng. 2014, 124, 132-136. [CrossRef]

57. Lemieux, A.; Shkarupin, A.; Sharp, K. Geologic feasibility of underground hydrogen storage in Canada. Int. J. Hydrog. Energy 2020, 45, 32243-32259. [CrossRef]

58. Hirscher, M.; Yartys, V.A.; Baricco, M.; Bellosta von Colbe, J.; Blanchard, D.; Bowman, R.C.; Broom, D.P.; Buckley, C.E.; Chang, F.; Chen, P.; et al. Materials for hydrogen-based energy storage-past, recent progress and future outlook. J. Alloy. Compd. 2020, 827, 153548. [CrossRef]

59. Crow, J.M. Hydrogen storage gets real. Chemistry World, 2019. Available online: https://www.chemistryworld.com/features/ hydrogen-storage-gets-real/3010794.article (accessed on 18 December 2020).

60. Collins, L. World First for Solid-State Green Hydrogen at Hybrid Solar Project. 2020. Available online: https://www. rechargenews.com/transition/world-first-for-solid-state-green-hydrogen-at-hybrid-solar-project/2-1-771319 (accessed on 18 December 2020).

61. Plug Power. Fuel Cells Products for Material Handling Equipment. 2020. Available online: https://www.plugpower.com/fuelcell-power/gendrive/ (accessed on 18 December 2020).

62. Kakoulaki, G.; Kougias, I.; Taylor, N.; Dolci, F.; Moya, J.; Jäger-Waldau, A. Green hydrogen in Europe-A regional assessment: Substituting existing production with electrolysis powered by renewables. Energy Convers. Manag. 2020, 113649, in press. [CrossRef]

63. Bhaskar, A.; Assadi, M.; Nikpey Somehsaraei, H. Decarbonization of the Iron and Steel Industry with Direct Reduction of Iron Ore with Green Hydrogen. Energies 2020, 13, 758. [CrossRef]

64. IEA. Global EV Outlook 2020. 2020. Available online: https://www.iea.org/reports/global-ev-outlook-2020 (accessed on 10 December 2020).

65. IEA. Global EV Outlook 2019. 2019. Available online: https://www.iea.org/reports/global-ev-outlook-2019 (accessed on 10 December 2020).

66. TCP, I.A. 2019 Survey on the Number of Fuel Cell Vehicles, Hydrogen Refueling Stations and Targets. $2019 . \quad$ Available online: https:/ / www.ieafuelcell.com/fileadmin/publications/2019-04_AFC_TCP_survey_status_FCEV_2018.pdf (accessed on 10 December 2020).

67. Wanitschke, A.; Hoffmann, S. Are battery electric vehicles the future? An uncertainty comparison with hydrogen and combustion engines. Environ. Innov. Soc. Transit. 2020, 35, 509-523. [CrossRef]

68. FuelCellsWorks. 600 HYPE Hydrogen Taxis Planned in Paris for the End of 2020. 2020. Available online: https:/ fuelcellsworks. com/news/thursday-throwback-spotlight-600-hype-hydrogen-taxis-planned-in-paris-for-the-end-of-2020/ (accessed on 10 December 2020).

69. Hall, M. Plans for 50,000 Hydrogen-Powered Taxis in Paris. 2020. Available online: https://www.pv-magazine.com/2020/11/ 12/plans-for-50000-hydrogen-powered-taxis-in-paris/ (accessed on 10 December 2020).

70. Bae, S.; Lee, E.; Han, J. Multi-Period Planning of Hydrogen Supply Network for Refuelling Hydrogen Fuel Cell Vehicles in Urban Areas. Sustainability 2020, 12, 4114. [CrossRef] 
71. Grüger, F.; Dylewski, L.; Robinius, M.; Stolten, D. Carsharing with fuel cell vehicles: Sizing hydrogen refueling stations based on refueling behavior. Appl. Energy 2018, 228, 1540-1549. [CrossRef]

72. Lee, D.Y.; Elgowainy, A.; Kotz, A.; Vijayagopal, R.; Marcinkoski, J. Life-cycle implications of hydrogen fuel cell electric vehicle technology for medium- and heavy-duty trucks. J. Power Sources 2018, 393, 217-229. [CrossRef]

73. El Hannach, M.; Ahmadi, P.; Guzman, L.; Pickup, S.; Kjeang, E. Life cycle assessment of hydrogen and diesel dual-fuel class 8 heavy duty trucks. Int. J. Hydrog. Energy 2019, 44, 8575-8584. [CrossRef]

74. Mulholland, E.; Teter, J.; Cazzola, P.; McDonald, Z.; Ó Gallachóir, B.P. The long haul towards decarbonising road freight-A global assessment to 2050. Appl. Energy 2018, 216, 678-693. [CrossRef]

75. Connolly, D. Economic viability of electric roads compared to oil and batteries for all forms of road transport. Energy Strategy Rev. 2017, 18, 235-249. [CrossRef]

76. Fuel Cells Bulletin. ASKO puts four Scania hydrogen fuel cell electric trucks into service in Norway. Fuel Cells Bull. 2020, 2020, 1. [CrossRef]

77. Fuel Cells Bulletin. H2-Share starts demo of hydrogen powered truck in Netherlands. Fuel Cells Bull. 2020, 2020, 4. [CrossRef]

78. Fuel Cells Bulletin. Clean Logistics JV converts diesel trucks to hydrogen-hybrid. Fuel Cells Bull. 2019, 2019, 4-5. [CrossRef]

79. Fuel Cells Bulletin. Air Liquide, Rotterdam link to foster hydrogen trucks, infrastructure. Fuel Cells Bull. 2020, 2020, 4. [CrossRef]

80. Lao, J.; Song, H.; Wang, C.; Zhou, Y.; Wang, J. Reducing atmospheric pollutant and greenhouse gas emissions of heavy duty trucks by substituting diesel with hydrogen in Beijing-Tianjin-Hebei-Shandong region, China. Int. J. Hydrog. Energy 2020. [CrossRef]

81. Kast, J.; Morrison, G.; Gangloff, J.J.; Vijayagopal, R.; Marcinkoski, J. Designing hydrogen fuel cell electric trucks in a diverse medium and heavy duty market. Res. Transp. Econ. 2018, 70, 139-147. [CrossRef]

82. Tyrol, H.S. The CHIC Project. 2020. Available online: https://www.h2-suedtirol.com/en/projects/chic/ (accessed on 6 December 2020).

83. Loría, L.E.; Watson, V.; Kiso, T.; Phimister, E. Investigating users' preferences for Low Emission Buses: Experiences from Europe's largest hydrogen bus fleet. J. Choice Model. 2019, 32, 100169. [CrossRef]

84. Hua, T.; Ahluwalia, R.; Eudy, L.; Singer, G.; Jermer, B.; Asselin-Miller, N.; Wessel, S.; Patterson, T.; Marcinkoski, J. Status of hydrogen fuel cell electric buses worldwide. J. Power Sources 2014, 269, 975-993. [CrossRef]

85. Lozanovski, A.; Whitehouse, N.; Ko, N.; Whitehouse, S. Sustainability Assessment of Fuel Cell Buses in Public Transport. Sustainability 2018, 10. [CrossRef]

86. Lee, D.Y.; Elgowainy, A.; Vijayagopal, R. Well-to-wheel environmental implications of fuel economy targets for hydrogen fuel cell electric buses in the United States. Energy Policy 2019, 128, 565-583. [CrossRef]

87. Piraino, F.; Genovese, M.; Fragiacomo, P. Towards a new mobility concept for regional trains and hydrogen infrastructure. Energy Convers. Manag. 2020, Article in press, 113650. [CrossRef]

88. Fuel Cells Bulletin. Hydrogen station for Hesse passenger trains. Fuel Cells Bull. 2020, 2020, 9. [CrossRef]

89. Fuel Cells Bulletin. Alstom, Eversholt Rail invest another $£ 1 \mathrm{~m}$ in Breeze hydrogen train. Fuel Cells Bull. 2020, 2020, 5. [CrossRef]

90. Fuel Cells Bulletin. Alstom, Snam develop hydrogen trains in Italy. Fuel Cells Bull. 2020, 2020, 4.

91. Bicer, Y.; Dincer, I. Environmental impact categories of hydrogen and ammonia driven transoceanic maritime vehicles: A comparative evaluation. Int. J. Hydrog. Energy 2018, 43, 4583-4596. [CrossRef]

92. Baroutaji, A.; Wilberforce, T.; Ramadan, M.; Olabi, A.G. Comprehensive investigation on hydrogen and fuel cell technology in the aviation and aerospace sectors. Renew. Sustain. Energy Rev. 2019, 106, 31-40. [CrossRef]

93. Airbus. Airbus ZEROe Project. 2020. Available online: https://www.airbus.com/newsroom/stories/these-new-Airbus-conceptaircraft-have-one-thing-in-common.html (accessed on 6 December 2020).

94. Lo Basso, G.; Nastasi, B.; Astiaso Garcia, D.; Cumo, F. How to handle the Hydrogen enriched Natural Gas blends in combustion efficiency measurement procedure of conventional and condensing boilers. Energy 2017, 123, 615-636. [CrossRef]

95. Schiro, F.; Stoppato, A.; Benato, A. Modelling and analyzing the impact of hydrogen enriched natural gas on domestic gas boilers in a decarbonization perspective. Carbon Resour. Convers. 2020, 3, 122-129. [CrossRef]

96. Wahl, J.; Kallo, J. Quantitative valuation of hydrogen blending in European gas grids and its impact on the combustion process of large-bore gas engines. Int. J. Hydrog. Energy 2020, 45, 32534-32546. [CrossRef]

97. Meziane, S.; Bentebbiche, A. Numerical study of blended fuel natural gas-hydrogen combustion in rich/quench/lean combustor of a micro gas turbine. Int. J. Hydrog. Energy 2019, 44, 15610-15621. [CrossRef]

98. H21. H21 Project. 2016. Available online: https:/ / www.h21.green/ (accessed on 6 December 2020).

99. Hy4Heat. Hy4Heat Project. 2018. Available online: https://www.hy4heat.info/ (accessed on 6 December 2020).

100. Worcester-Bosch. Hydrogen-Fired Boiler. 2020. Available online: https://www.worcester-bosch.co.uk/hydrogen (accessed on 6 December 2020).

101. SNG. H100 Fife Project. 2020. Available online: https://www.sgn.co.uk/H100Fife (accessed on 6 December 2020).

102. Taanman, M.; de Groot, A.; Kemp, R.; Verspagen, B. Diffusion paths for micro cogeneration using hydrogen in the Netherlands. J. Clean. Prod. 2008, 16, S124-S132. [CrossRef]

103. Lokar, J.; Virtič, P. The potential for integration of hydrogen for complete energy self-sufficiency in residential buildings with photovoltaic and battery storage systems. Int. J. Hydrog. Energy 2020, 45, 34566-34578. [CrossRef]

104. McPherson, M.; Johnson, N.; Strubegger, M. The role of electricity storage and hydrogen technologies in enabling global low-carbon energy transitions. Appl. Energy 2018, 216, 649-661. [CrossRef] 
105. Ozawa, A.; Kudoh, Y.; Kitagawa, N.; Muramatsu, R. Life cycle $\mathrm{CO}_{2}$ emissions from power generation using hydrogen energy carriers. Int. J. Hydrog. Energy 2019, 44, 11219-11232. [CrossRef]

106. Matsuo, Y.; Endo, S.; Nagatomi, Y.; Shibata, Y.; Komiyama, R.; Fujii, Y. A quantitative analysis of Japan's optimal power generation mix in 2050 and the role of $\mathrm{CO}_{2}$-free hydrogen. Energy 2018, 165, 1200-1219. [CrossRef]

107. Shulga, R.; Putilova, I.; Smirnova, T.; Ivanova, N. Safe and waste-free technologies using hydrogen electric power generation. Int J. Hydrog. Energy 2020, 45, 34037-34047. [CrossRef]

108. Kafetzis, A.; Ziogou, C.; Panopoulos, K.; Papadopoulou, S.; Seferlis, P.; Voutetakis, S. Energy management strategies based on hybrid automata for islanded microgrids with renewable sources, batteries and hydrogen. Renew. Sustain. Energy Rev. 2020, 134, 110118. [CrossRef]

109. Kalamaras, E.; Belekoukia, M.; Lin, Z.; Xu, B.; Wang, H.; Xuan, J. Techno-economic Assessment of a Hybrid Off-grid DC System for Combined Heat and Power Generation in Remote Islands. Energy Procedia 2019, 158, 6315-6320. [CrossRef]

110. Gracia, L.; Casero, P.; Bourasseau, C.; Chabert, A. Use of Hydrogen in Off-Grid Locations, a Techno-Economic Assessment. Energies 2018, 11, 3141. [CrossRef]

111. Pflugmann, F.; Blasio, N.D. Geopolitical and Market Implications of Renewable Hydrogen. New Dependencies in a LowCarbon Energy World. 2020. Harvard Belfer Center for Science and International Affairs, Report, March 2020. Available online: https:/ / www.belfercenter.org/sites/default/files/files/publication/Geopolitical\%20and\%20Market\%20Implications\% 20of\%20Renewable\%20Hydrogen.pdf (accessed on 18 December 2020).

112. IRENA. Green Hydrogen: A Guide to Policy Making. 2020. International Renewable Energy Agency, Abu Dhabi, November 2020. Available online: https:/ / www.irena.org/publications/2020/Nov/Green-hydrogen (accessed on 18 December 2020).

113. Hikima, K.; Tsujimoto, M.; Takeuchi, M.; Kajikawa, Y. Transition Analysis of Budgetary Allocation for Projects on HydrogenRelated Technologies in Japan. Sustainability 2020, 12, 8546. [CrossRef]

114. Meng, X.; Gu, A.; Wu, X.; Zhou, L.; Zhou, J.; Liu, B.; Mao, Z. Status quo of China hydrogen strategy in the field of transportation and international comparisons. Int. J. Hydrog. Energy 2020, in press. [CrossRef]

115. SPGLOBAL. How Hydrogen Can Fuel The Energy Transition. 2020. Comments, 19 November 2020. Available online: https: //www.spglobal.com/ratings/en/research/articles/201119-how-hydrogen-can-fuel-the-energy-transition-11740867 (accessed on 18 December 2020).

116. Kan, S. South Korea's Hydrogen Strategy and Industrial Perspectives. 2020. IFRI, Édito Énergie, 25 March 2020. Available online: https:/ / www.ifri.org/sites/default/files/atoms/files/sichao_kan_hydrogen_korea_2020_1.pdf (accessed on 18 December 2020).

117. RystadEnergy. Hydrogen Wars: Governments Race to Boost Green Hydrogen Production; 2020, Rystad Energy, Oslo, Norway.

118. Hartley, P.G.; Au, V. Towards a Large-Scale Hydrogen Industry for Australia. Engineering 2020, 6 (12), 1346-1348. [CrossRef]

119. Council, T.A. The ACWA Power-Air Products Joint Venture for gReen Hydrogen: A New Saudi Energy Policy? 2020. Atlantic Council, 24 July 2020. Available online: https:/ / www.atlanticcouncil.org/blogs/energysource/the-acwa-power-air-productsjoint-venture-for-green-hydrogen-a-new-saudi-energy-policy/ (accessed on 18 December 2020).

120. SPGLOBAL. UAE Investing in Green and Blue Hydrogen Projects as Part of Clean Energy Move: Official. 2020. Available online: https:/ /www.spglobal.com/platts/en/market-insights/latest-news/electric-power/101920-uae-investing-in-green-andblue-hydrogen-projects-as-part-of-clean-energy-move-official (accessed on 18 December 2020).

121. Smith, M. Morocco aims for global green hydrogen role. Hydrogen Economist, 2020. Available online: https://pemedianetwork. com/hydrogen-economist/articles/green-hydrogen/2020/morocco-aims-for-global-green-hydrogen-role (accessed on 18 December 2020).

122. Ishikawa, Y. Russia plans to export hydrogen to Asia in green shift. Asia Nikkei, 2020. Available online: https: / / asia.nikkei.com/Editor-s-Picks/Interview/Russia-plans-to-export-hydrogen-to-Asia-in-green-shift\#: :text=Russia\% 20produces\%20hydrogen\%20now\%20for,increase\%20it\%20tenfold\%20by\%202035 (accessed on 18 December 2020).

123. Strategy\&. The Dawn of Green Hydrogen-Maintaining the GCC's Edge in a Decarbonized World. 2020. Available online: https: //www.strategyand.pwc.com/m1/en/reports/2020/the-dawn-of-green-hydrogen/the-dawn-of-green-hydrogen.pdf (accessed on 11 December 2020).

124. European Hydrogen Backbone Initiative. European Hydrogen Backbone. 2020. Available online: https:/ /gasforclimate2050.eu/ sdm_downloads/european-hydrogen-backbone/ (accessed on 18 December 2020).

125. Franke, A.; Baratti, G. Green Hydrogen: A Guide to Policy Making. 2020. S\&P Global Platts, 9 December 2020. Available online: https://www.spglobal.com/platts/en/market-insights/latest-news/metals/120920-european-groups-join-hydrogenproject-targeting-2kg-production (accessed on 18 December 2020).

126. Ratcliffe, V. Saudi Arabia Sends Blue Ammonia to Japan in World-First Shipment. 2020. Available online: https://www. bloomberg.com/news/articles/2020-09-27/saudi-arabia-sends-blue-ammonia-to-japan-in-world-first-shipment (accessed on 11 December 2020).

127. Velazquez Abad, A.; Dodds, P.E. Green hydrogen characterisation initiatives: Definitions, standards, guarantees of origin, and challenges. Energy Policy 2020, 138, 111300. [CrossRef] 